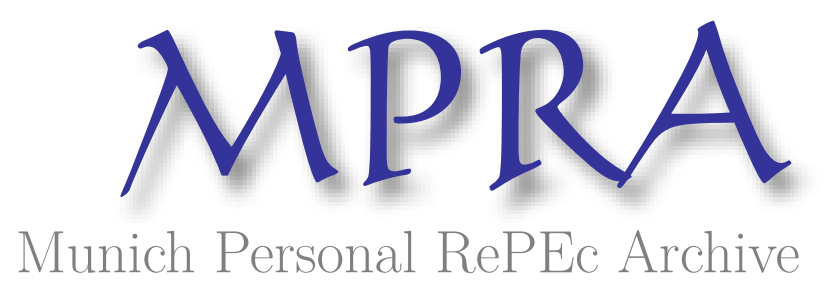

\title{
How Trade and Investment Agreements Affect Bilateral Foreign Direct Investment: Results from a Structural Gravity Model
}

Kox, Henk L.M. and Rojas-Romagosa, Hugo

KVL Economic Policy Analysis, World Bank

March 2020

Online at https://mpra.ub.uni-muenchen.de/102494/

MPRA Paper No. 102494, posted 21 Aug 2020 13:44 UTC 


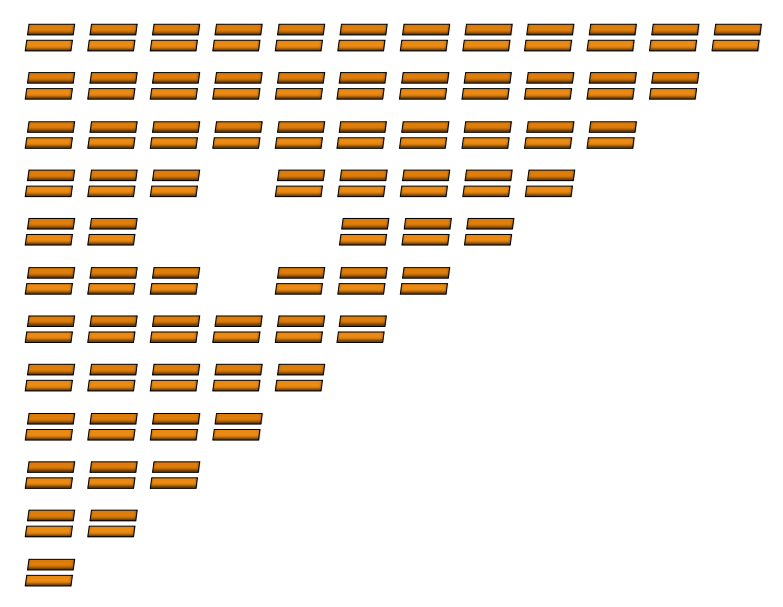

How Trade and Investment Agreements Affect Bilateral Foreign Direct Investment:

Results from a Structural Gravity Model

Henk L.M. Kox and Hugo Rojas Romagosa 


\title{
Colophon
}

KVL Discussion Papers are published to disseminate academic research results, stimulate scientific discussion and the recombination of ideas. The KVL Discussion Papers do not necessarily reflect the opinion of KVL Economic Policy Research. Only the authors are responsible for the contents of a Discussion Paper.

\author{
KVL Economic Policy Research \\ Reitscheweg 1-7, $5232 \mathrm{BX}$ \\ Den Bosch, The Netherlands \\ contact: admin@kvl-epr.eu
}

\begin{abstract}
:
The paper develops a new stand-alone structural gravity model for explaining bilateral FDI patterns. We employ the model to analyse the impact of preferential trade agreements (PTAs), bilateral investment treaties (BITs) and other policies on bilateral foreign direct investment (FDI). We use the UNCTAD global database on bilateral FDI stocks and flows. To control for the heterogeneous nature of PTAs, we employ two different indicators of PTA depth. We find that on average signing a PTA increases bilateral FDI stocks by around $30 \%$. Nevertheless, we also find that 'deeper' or comprehensive PTAs (e.g., including provisions on investment, public procurement and intellectual property rights provisions) do not have a significantly different impact than signing regular PTAs. Belonging to the EU single market, on the other hand, has a strong impact and increases bilateral FDI by around $135 \%$, and signing a BIT has an effect that is comparable to signing a PTA..
\end{abstract}

JEL codes: F21, F15, C33, C54

Keywords: bilateral FDI, depth of preferential trade agreements, bilateral investment treaties, structural gravity model 


\title{
How trade and investment agreements affect bilateral FDI: Results from a structural gravity model
}

\author{
Henk L. M. Kox and Hugo Rojas-Romagosa
}

March 2020

\begin{abstract}
We employ a structural gravity approach to analyse the impact of preferential trade agreements (PTAs), bilateral investment treaties (BITs) and other policies on bilateral foreign direct investment (FDI). We use the UNCTAD global database on bilateral FDI stocks and flows. To control for the heterogeneous nature of PTAs we employ two different indicators of PTA depth. We find that on average signing a PTA increases bilateral FDI stocks by around $30 \%$. Nevertheless, we also find that 'deeper' or comprehensive PTAs (e.g. including provisions on investment, public procurement and intellectual property rights provisions) do not have a significantly different impact than signing regular PTAs. Belonging to the EU single market, on the other hand, has a strong impact and increases bilateral FDI by around $135 \%$, and signing a BIT has an effect that is comparable to signing a PTA.
\end{abstract}

\section{Introduction}

We estimate the potential impact of preferential trade agreements (PTAs) and other bilateral policies that affect trade and investment- on the bilateral FDI stocks and flows between the countries signing these agreements. Our key results are based on a structural gravity model of FDI that is applied to bilateral FDI data from UNCTAD (2014), while controlling for the presence, heterogeneity and depth of preferential trade agreements (PTAs), and other time-varying bilateral policies.

Starting in the 1990s, the world economy has experienced a large increase in the number of PTAs, and also in their 'depth' - measured by the number 
of their operative provisions. ${ }^{1}$ While stimulating bilateral trade is the main focus of most PTAs, recent preferential trade agreements increasingly contain provisions on bilateral investment between member states. However, the impact of PTAs on the magnitude of foreign direct investments is not straightforward. Trade and FDI can either complement or substitute each other, depending on the investment motivation (i.e. horizontal, vertical), the specific industry and on the way in which the FDI provisions are shaped in the PTA. From a theoretical point of view, horizontal FDI -where firms replicate domestic activities in a foreign country- are associated with FDI substituting for trade. Thus, in the presence of horizontal FDI, PTAs are expected to decrease FDI flows. On the other hand, vertical FDI -where firms split activities between different geographical regions- creates a complementary relationship between trade, PTAs and FDI (cf. Markusen, 2002). More recently, and in part due to the expansion and complexity of global value chains (GVCs), other motives for FDI have been identified. For instance, export-platform FDI where MNEs produce to export to third markets (Hanson et al., 2005; Ekholm et al., 2007), while Yeaple (2003) classifies mixed motives as 'complex FDI'. Baldwin and Okubo (2014) develop the concepts of 'horizontal-ness' and 'vertical-ness' to systematically classify these more complex forms of FDI. Horizontal-ness is related to large shares of local sales, while vertical-ness is associated with large shares of local sourcing of intermediates. ${ }^{2}$ The links between trade and FDI, especially the role of complementarity (vertical-ness) and substitutability (horizontal-ness), most probably differ by industry. Hence, the industry composition of bilateral trade and FDI is also likely to affect how PTAs impact bilateral FDI.

There has also been an increasing gap between the refinement of theoretical FDI models and the availability of bilateral FDI data. The motivation or purpose of the investments is mostly not revealed, and it can only be inferred in an indirect way. Industry decomposition of bilateral FDI is only possible for a very small number of countries. ${ }^{3}$ Even the compilation of a

\footnotetext{
${ }^{1}$ See for example, Dür et al. (2014), Hofmann et al. (2017), and Miroudot and Rigo (2019).

${ }^{2}$ Combining these concepts Baldwin and Okubo (2014) create a two dimensional space that accommodates for all FDI motives and distinguish six main FDI motives: pure horizontal, pure vertical, pure export-platform, local assembly (tariff-jumping), resource extraction and networked FDI (global value chains).

${ }^{3}$ Alfaro and Charlton (2009) identify between vertical and horizontal FDI flows by employing the implicit information in national input-output tables. An alternative database, which has information at the industry level and has been used in some papers to estimate FDI gravity models is the fDiMarkets database (www.fdimarkets.com) of the Financial Times. However, this database has two main limitations: it only reports announced (in-
} 
consistent set of total bilateral FDI data between country pairs and at world level is a difficult task (IMF, 2003). It is common that two partner countries report different bilateral FDI values. Thus, a detailed reconciliation of the data and a compilation methodology is required. In this study we employ such a compilation, done by the UNCTAD (2014) database, which provides bilateral data on inward and outward FDI flows and stocks. ${ }^{4}$

Since we cannot separate the FDI data between horizontal and vertical FDI, the expected relation between PTAs, trade and FDI remains an empirical question. Bergstrand and Egger (2007) test a model with three countries with export and FDI and they find that regional integration has a positive trade effect, but a negative effect on FDI. This suggests a substitutability relation between trade and FDI. Other studies that employ panel data with a larger set of countries, find the opposite results (Daude et al., 2003; Chen, 2009; Osnago et al., 2017; Anderson et al., 2019, 2020). The latter studies find empirical support for a complementary relation between trade and FDI, which might well include the creation or expansion of global value chains via PTAs. ${ }^{5}$ The analytical framework of our own paper is closest to Anderson et al. (2019), in which they develop a structural gravity module for bilateral FDI as part of a larger general equilibrium model. However, there are four important differences between our paper and theirs. First, our paper fully focuses on the direct impact of PTAs on bilateral FDI using a partial equilibrium model, whereas they want to obtain the general-equilibrium effects of PTAs on welfare. ${ }^{6}$ Secondly, we allow for the possibility that the relative FDI friction costs, i.e. the multilateral resistance terms with respect to FDI, may differ from the bilateral trade-costs frictions. In Anderson et al. (2019), the multilateral resistance terms are exclusively based on the bilateral trade-costs frictions. Following Bergstrand and Egger (2007) and Bergstrand and Egger (2010) both trade and FDI flows are driven by a 'com-

stead of actual) investments and it only has information on green-field investment rather than on total FDI. These serious database limitations do not allow for the country-wide analysis we conduct in this paper.

${ }^{4}$ In particular, our main estimations employ the inward FDI stock data, which fluctuates less and is in general more reliable than year-to-year FDI flow data. Nonetheless, we also use inward FDI flows to assess the robustness of our results.

${ }^{5}$ Osnago et al. (2017), in particular, test the effect of deep PTAs on vertical FDI, and not surprisingly, they find a positive relation. Like our paper, they also focus on the depth of PTAs. However, we use a global database that includes both horizontal and vertical bilateral FDI.

${ }^{6}$ The aim of the Anderson et al. $(2019,2020)$ papers is to obtain the PTAs' general equilibrium effects through trade and FDI effects on real income. We want to focus on the effect of PTAs on FDI and we are not concerned with the trade nor the general equilibrium effects that translate into welfare changes. 
mon process'. According to these authors, this implies that including trade flows as explanatory variables in a (partial equilibrium) gravity equation for FDI flows (or vice versa) is a serious mis-specification of the estimations and it is likely to create an endogeneity bias. Therefore, we do not use trade flows in our FDI gravity estimations. Employing only FDI data is sufficient for our purposes to assess whether PTAs have a significant impact on bilateral FDI patterns. Thirdly, we allow for the heterogeneity (depth) of PTAs, while they only include a dummy variable for the presence of any PTA. The fourth and final difference is that we generate a larger number of sensitivity analyses to confirm the robustness of the effect of PTAs on FDI.

The contribution of this paper is that we present a stand-alone partial equilibrium model explaining bilateral FDI patterns. We empirically estimate the sign and magnitude of the effect that preferential trade agreements have on FDI, conditional on the depth of the PTA and the presence of other bilateral or multilateral policies - e.g. being member of the EU single market, the presence of a bilateral investment treaty. We find that PTAs have a significant and positive effect on bilateral FDI of around 30\%. This effect is slightly larger (35\%) for the deepest PTAs, but this result is not statistically different from just having any PTA -irrespective of its depth- and it is not robust in many alternative specifications. Therefore, an important finding of this paper is that we do not find that signing a comprehensive PTA has an empirically larger effect than just signing a 'shallow' PTA. On the other hand, we find that country-pairs that belong to the EU single market experience a very substantial increase in bilateral FDI of around $135 \%$. Therefore, we argue that it is crucial to control for the EU single market, when estimating the impact of deep PTAs. Otherwise, the effect of deep PTAs (when assuming that the EU single market is a deep PTA) is overstated. Finally, we find that the sign and magnitude of the average PTA effect, of being member of the EU single market, and of participating in a bilateral investment treaty (BIT), are robust to different econometric specifications. Indirectly, these results can be interpreted as pointing to a higher relative importance of vertical over horizontal FDI, by associating the trade-cost reductions of PTAs to the nature of the PTA-FDI relation.

This paper is organised as follows. In Section 2 we survey the theoretical background linking PTAs with FDI. Section 3 explains our analytical framework and econometric specification. The data is presented in Section 4 and our main structural gravity results are shown in Section 5. In Section 6 we run several sensitivity analysis and we conclude in Section 7. 


\section{Theoretical background}

Reviewing the literature on FDI determinants, Blonigen (2005) remarks: 'Ideally, the FDI literature would have an established model and empirical specification that lays out the primary long-run determinants of FDI location'. He concludes however that such a model does not yet exist. Given the success of the gravity trade model one wonders why it has not yet become part of the standard empirical toolkit for the analysis of international patterns in bilateral FDI. In a recent publication, Allen et al. (2020) generalise the gravity trade model by unifying a large set of trade and geography models, showing that the properties of models within this framework depend crucially on the value of two gravity constants (aggregate supply and demand elasticities). While their publication carries the title 'Universal Gravity', they do not extend their theory to FDI. This might not be a coincidence. In this context, Blonigen (2005) again asserts: 'As with trade flows, a gravity specification actually fits cross-country data on FDI reasonably well. However, there is no similar paper to Anderson and van Wincoop (2003) that lays out a tractable model that specifically identifies gravity variables as the sole determinants of FDI patterns'. The gravity model has mainly been used in empirical studies on FDI without a real theory that predicts a gravity-like pattern. ${ }^{7}$

On the other side of the spectrum there are new theories for explaining the relations between trade, FDI and the operations of multinational corporations. Yet, here again we hit the gap between the refinement of theoretical models and the availability of bilateral direct investment data. Despite the fact that they predict gravity-like patterns, these new models are too complex and data-demanding for testing with actual data, and therefore only allow calibrated exercises. For instance, several recent studies on FDI (Bergstrand and Egger, 2007, 2010; Ramondo and Rodríguez-Clare, 2013; Anderson et al., 2019, 2020) have tried to widen the scope of analysis by explaining trade and FDI in the same models, e.g. by discussing the trade versus FDI substitution effects. FDI is linked with capital accumulation, economic growth and also with trade. But to try and understand these phenomena in an integrated model leads into a quagmire of nested causal relations. Anderson et al. (2019) use a calibrated model for a tentative analysis of the dynamic interaction of FDI, capital accumulation, trade and GDP growth in 89 countries. The FDI equation forms a sub-system

\footnotetext{
${ }^{7}$ (Cf. Brainard, 1997; Egger and Pfaffermayr, 2004; Braconier et al., 2005; Kleinert and Toubal, 2010; Davies and Kristjansdottir, 2010).
} 
of their overall model, so it cannot be used as a stand-alone explanation of bilateral FDI patterns. In a simpler setting - using a 3-country, 3-factor, 2-goods model- Bergstrand and Egger $(2007,2010)$ study the interaction of FDI flows with trade in final and intermediate goods, but also do not obtain a closed-form gravity model for FDI. They find some indications for substitution between trade and FDI using a calibrated model to fit the data. ${ }^{8}$ Similarly, Ramondo and Rodríguez-Clare (2013) present a more sophisticated theoretical model for joint analysis of the interaction between trade and different multinational strategies. They also show how this interaction impacts the economic gains from economic openness. This model was later expanded to an even more comprehensive economic model that could also explain domestic innovation investment (Arkolakis et al., 2018). Although these large models offer a coherent and often inspiring overview of the current research areas, the empirical testing of their central theoretical predictions has become problematic because of their comprehensiveness. In a methodological study on the assessment of causality relations, Pearl (2009) argues that large integrated model structures are difficult to falsify, because they rest on many parameters and behavioural assumptions for which no direct measurement or other empirical data is available. ${ }^{9}$ This makes it difficult to design and implement unambiguous empirical falsification tests. A key empirical issue is the identification of the causal mechanisms in such large models Lewbel (2019). An increasingly common practise is to render such large models some plausibility by running calibrated data exercises. Because large models offer ample opportunity to over-fit the data, the results of such calibration exercises must be regarded with caution.

In this paper we take a different approach. We explain world-wide bilateral FDI patterns by the smallest possible model. We deliberately opt for a partial equilibrium model that explains the main push and pull factors for FDI and that also accounts for absolute and relative bilateral FDI frictions. Absolute FDI frictions can be formed by explicit restrictions on incoming FDI. Legal and statutory restrictions are a form of absolute FDI frictions, because they create a negative constraint on firm-level optimising behaviour. Relative FDI frictions also account for other economic policy elements that can make FDI less or more attractive (profitable), both in the host country and in the origin country, when compared to all other countries. Most push and pull factors are directly or indirectly linked to GDP, which represents a

\footnotetext{
${ }^{8}$ Bergstrand and Egger (2007) do calibrated exercises on the interaction between trade and FDI, because their model specification does not allow full empirical testing.

${ }^{9}$ This also holds for Ramondo and Rodríguez-Clare (2013) and Arkolakis et al. (2018).
} 
country's economic mass. This model specification means that we do not test the interrelation between PTAs, trade and FDI. This avoids the endogeneity bias related to trade and FDI flows being generated by a common process that can mis-specify the estimations (cf. Bergstrand and Egger, 2007, 2010). Our model builds on the knowledge capital or knowledge-capital interpretation of FDI. ${ }^{10} \mathrm{FDI}$ is assumed to be comparable with trade in technology services. A given stock of knowledge capital (e.g. patents, blueprints, management skills, business model and brands) can be used simultaneously in more than one country, on a non-rival basis. The value of the knowledge capital increases when it can be 'leased' to other countries in the form of FDI. Both the use of foreign knowledge capital in the form of incoming FDI, and the size of the origin countries' stock of 'leasable' knowledge capital (outgoing FDI) are proportional to GDP. Our model takes the current and past distribution of economic masses (GDP) of both origin and host countries as an exogenous input. The amount of bilateral FDI rises as absolute and relative FDI frictions diminish. The incidence and depth of PTAs could lower both absolute and relative FDI friction costs, and thus increase bilateral FDI between the member countries. We test for this hypothesis, while controlling for the presence of other shocks in bilateral FDI frictions: EU membership and the presence of bilateral investment treaties.

\section{Analytical framework}

This section provides details on the structural gravity model for FDI, our quantitative strategy, and the precise empirical specifications that we employ.

\subsection{Theoretical gravity model for FDI}

Our FDI gravity model is related to the modelling approach developed by Anderson et al. (2019, 2020). Nonetheless, there are important differences, as was already mentioned in the introduction. The FDI gravity module in Anderson et al. (2019) is part of a larger general equilibrium model that aims to assess the effects that PTAs through trade, FDI and capital accumulation have on welfare. The model has an aggregated setup, with total trade and total FDI. The issue of complementary (vertical-ness) and substitutability (horizontal-ness) of trade-FDI links is only touched in a crude calibrated simulation in which they compare a world with and without FDI.

${ }^{10}$ Developed inter alia by Markusen (2002) and McGrattan and Prescott (2009, 2010). 
Their model is restrictive by assuming that the relative FDI friction costs (multilateral resistance terms) are the same as the relative trade friction costs. Finally, their modelling of PTA membership by a binary dummy is not adequate for our aim.

We adapt the FDI module of Anderson et al. (2019) so that it can be used as a stand-alone partial-equilibrium model for exploring the direct impacts of different PTA designs on bilateral FDI. The largest restriction of our model is that we totally ignore bilateral trade flows and focus exclusively on bilateral FDI patterns. The model is based on the knowledge-capital interpretation of FDI, where this type of capital assumes proprietary knowledge that can be used on a non-rival basis in several locations. Firms increase the value of their proprietary knowledge capital by 'leasing' it to other countries in the form of FDI. Flows of knowledge capital are to a large extent intangible and therefore difficult to measure. We use the stock of bilateral FDI as a proxy for the flow of knowledge (technology) capital between two countries. Anderson et al. (2019) implicitly assume that FDI frictions are the same as trade frictions, but there is no evidence for this assertion and we therefore concentrate on FDI frictions. In our model, the free flow of knowledge capital across national borders is hindered by absolute and relative FDI frictions. Absolute FDI frictions are legal and statutory barriers that a country imposes on the access of foreign FDI capital. This includes total bans, negative lists that specify restrictions to the activity of multinationals in specific industries, protection of national champions, or any other access-related policy measures. Relative FDI frictions refer to opportunity costs of operation in a host country $j$ compared to the operating costs in all other potential alternative location choices. It includes a host of operational costs, such as distance (transport), infrastructure, communication (language differences), legal system (enforceability of contracts), government characteristics (efficiency, degree of business-mindedness, stability), labour costs, corporate tax rate, corruption, and security (insurance and contingency costs). The absolute FDI frictions dominate and precede the relative FDI friction by setting the negative constraints that frame the choice possibilities for FDI location choice. For our model, it is important to note that PTAs can have an impact on both absolute and relative FDI frictions.

We move on to the core of the formal model. ${ }^{11}$ The value of bilateral FDI originating from country $i$ and hosted in country $j$ is represented by $F D I_{i j}^{\text {stock }}$. It is positively affected by the size of the country of origin $\left(Y_{i}\right)$, because larger economies tend to invest more in knowledge capital. The

\footnotetext{
${ }^{11}$ For further details, see Annex A.1 where we derive the full model.
} 
bilateral FDI stock is also positively impacted by the size of the destination country $\left(Y_{j}\right)$, because larger economies have more consumers, firms and industries that can absorb foreign FDI technology. Thus, $Y_{i}$ and $Y_{j}$ are proxies for the economic mass of the origin and destination country. Both are proxied using real GDP values. The free flow of FDI is hindered firstly by absolute FDI frictions. If $\omega_{i j}=1$, country $j$ is fully open for entry of knowledge capital from country $i$, and if $\omega_{i j}=0$, no knowledge capital originating from country $i$ is admitted. FDI decisions also depend on relative FDI cost frictions that reflect the opportunity costs of choosing one particular FDI destination country versus all other countries. For origin country $i, P_{i}$ represents the average of inward relative friction costs in all destination countries, weighted by their economic mass. Larger $P_{i}$ makes FDI less attractive and it will lower the volume of bilateral investment. Relative friction costs may also arise in the origin countries themselves, e.g. via extraterritorial regulations for firms that have outward FDI. For the destination countries this may matter, and it will lower inward FDI from such countries. Therefore, we also account for the factor $\Pi_{j}$, which stands for the average of outward friction costs of all countries that invest in destination country $j$.

The aforementioned elements are the main determinants of bilateral FDI stocks. Our equation for bilateral FDI has the 'classical' structural gravity form as defined in Head and Mayer (2014): ${ }^{12}$

$$
F D I_{i j}^{\text {stock }}=\omega_{i j} \frac{\alpha Y_{i}}{P_{i}} \frac{\beta Y_{j}}{\Pi_{j}}
$$

The parameters $\alpha>0$ and $\beta>0$ are both gravity proportionality factors. They indicate how strong the bilateral FDI stocks react to the economic masses of, respectively, the origin and the destination country. ${ }^{13}$ Finally, $P_{i}$ and $\Pi_{j}$ are the FDI-based multilateral resistance terms of the structural gravity trade model. These aggregators normalise the (relative) FDI friction costs of each country pair with the average friction costs in other countries.

The inward multilateral resistance $(\mathrm{MR})$ term $\left(P_{i}\right)$ uses the CES constant elasticity of substitution $\sigma$ for a consistent aggregation and averaging of all national FDI friction costs, after weighing them by the relative economic size of each country. ${ }^{14} P_{i}$ is the time-variant MR term from the perspective

\footnotetext{
${ }^{12}$ Time indexes are suppressed in this representation.

${ }^{13}$ Without loss of generality we assume these factors to be the same for all origin and destination countries.

${ }^{14}$ In particular, we use $\sigma>1$, which results in all countries having a preference for variety of products and knowledge capital by country of origin.
} 
of origin country $i$, and averaging across all potential partner countries:

$$
P_{i}=\left[\sum_{j=1}^{N}\left(\frac{z_{i j}}{\Pi_{j}}\right)^{(1-\sigma)} \frac{Y_{j}}{Y}\right]^{\frac{1}{1-\sigma}}
$$

in which $z_{i j}$ is a measure for the FDI cost frictions that affect FDI originating from country $i$ and going to country $j$. These costs may be directionspecific -i.e. non-symmetric: $z_{i j}$ may differ from $z_{j i}$. Some cost elements may be symmetric like the effects of distance, the costs of having different languages, or even the costs of having different legal systems. Other costs elements, however, may be non-symmetric like the additional business costs due to national policies that are specific for destination country $j$. All friction elements increase the costs of bilateral FDI, but the relevant question is whether the investing firms have better alternative FDI locations. This depends on two factors. Firstly, the term $\frac{z_{j i}}{\Pi_{j}}$ measures the relative friction costs by normalising $z_{i j}$ with the average cost aggregator $\Pi_{j}$ (i.e. the outward MR term, which is explained below). If $\frac{z_{j i}}{\Pi_{j}}<1$, the relative FDI friction costs are less than average and may not form an obstacle for bilateral FDI, but in the opposite case they do obstruct FDI. The second factor is the size of country $j$ 's economy, as measured by its relative economic mass $\left(\frac{Y_{j}}{Y}\right)$, in which $Y=\sum Y_{j}$, is world output or world GDP. The combination of both elements decides whether a country is a preferred FDI location. A good score on one element may compensate a bad score on the other element. Countries that have the combination of a small economy and relatively high FDI friction costs may expect the least FDI, while most FDI will go to large countries with relatively low FDI friction costs.

The structural gravity model also accounts for differences in the policyrelated and geographical characteristics of each FDI origin. Such differences may affect the willingness and behaviour of national firms to engage in outward direct investment projects. Because the gravity model is all about the proportionality between economic mass and the intensity of cross-border transactions, we must also account for such frictional (disturbance) factors. When we consider incoming FDI from the perspective of destination country $j$, less bilateral FDI is expected per dollar of the origin country $i$ 's GDP, when country $i$ has higher than average outward friction costs. The full FDI gravity system, therefore, also holds the term $\Pi_{j}$, representing the average outward multilateral resistances for origin countries that invest in country 
$j$, which is aggregated in a similar way as in Equation 2:

$$
\Pi_{j}=\left[\sum_{i=1}^{N}\left(\frac{z_{j i}}{P_{i}}\right)^{(1-\sigma)} \frac{Y_{i}}{Y}\right]^{\frac{1}{1-\sigma}}
$$

Equation 3 uses country $i$ 's average inward MR terms $P_{i}$ to normalise the outward bilateral friction costs $z_{j i}$. Less bilateral FDI per dollar of origin country $i$ 's GDP may be expected when it has higher than average outward friction $\operatorname{costs}\left(\frac{z_{j i}}{P_{i}}>1\right)$. Again, this may be compensated if country $i$ has higher than average economic mass $\left(Y_{i} / \bar{Y}>1\right) .{ }^{15}$

The inward and outward multilateral resistance terms $\left(P_{i}\right.$ and $\Pi_{j}$, respectively) are theoretical constructs that capture general equilibrium effects, which usually are not directly observable. They allow to calculate the relative FDI friction costs that together with absolute FDI barriers represented by the openness measure $\omega_{i j}$ - determine how much inward FDI stocks a destination country is expected to receive from a particular origin country. The inward MR terms can provide valuable policy-relevant information. For instance, one could use the inward MR terms to identify those national policies that could be most effective in attracting FDI inflows. ${ }^{16}$

Equations 1 to 3 define the core gravity model of FDI. ${ }^{17}$ The model can be tested empirically on the basis of its predictions for bilateral FDI. In particular, we expect that bilateral FDI should be positively related to the GDP of origin and host countries. On the other hand, it should be negatively affected by relative FDI friction costs, such as transportation and communication costs (physical distance, lacking a common language, lacking a common border), costs of having different legal and regulatory regimes (lacking common institutions, no common history), and by having other policy-made barriers to bilateral trade and FDI.

This leads us to the main empirical question for this study: how are the FDI friction factors affected by the presence and the 'depth' of PTAs? To answer this question we extend the model to formally derive testable hypotheses. For the incidence of a common PTA membership we use the dummy variable $D_{i j}$ that has the value of 1 when country $i$ and country $j$

\footnotetext{
${ }^{15}$ Mutatis mutandis, the opposite holds for countries with lower than average outward friction costs. For example, because they are neighbouring countries, or because they have governments that stimulate foreign investments.

${ }^{16}$ In Kox and Rojas-Romagosa (2019) we further explore the empirical impact of inward MRs on FDI flows and their relation with national policy variables. See Kox and Rojas-Romagosa (2018) for an application to the Pacific Alliance and Kox (2018) for the Philippines.

${ }^{17}$ More details on the derivation of the base model can be found in Appendix A.1.
} 
are part of the same PTA, and the value of 0 otherwise. For the depth of the PTA we use the variable $Q_{i j}$, that may have $h$ values (degrees of PTA depth). We then expect negative partial differentials of bilateral access variable $\omega_{i j}$ and the relative friction costs $\frac{z_{i j}}{\Pi_{i j}}$ with respect to $D_{i j}$ and $Q_{i j}$. Consequently, the model predicts positive partial differentials of $F D I_{i j}$ with respect to $D_{i j}$ and $Q_{i j}{ }^{18}$ To test the robustness of our estimations we experiment with different PTA depth indexes and with different economic integration indicators. ${ }^{19}$ With our gravity model we can empirically test the following formal hypotheses:

1. Shared membership in any PTA increases FDI openness and/or lowers relative FDI friction costs. Both effects increase bilateral FDI.

2. Shared membership of deeper PTAs increases FDI openness and/or lowers relative FDI friction costs. Both effects increase bilateral FDI.

3. Deeper PTAs impact FDI openness, relative FDI friction costs and bilateral FDI more than PTAs with average depth. ${ }^{20}$

Finally, it is important to note that the introduction of a new PTA probably increases the relative FDI friction term (multilateral resistance term) for non-member states. Thus, there could be FDI-diversion effects that generate relative decreases of bilateral FDI for non-member countries. These effects should be stronger if large countries participate in the new PTA. However, because these FDI-diversion effects are spread over many nonmember countries, it is probably only measurable if a proper counterfactual is developed that keeps all other circumstances constant. This exercise is beyond the scope of our study, and might require a full general equilibrium approach.

\subsection{Estimation of the structural gravity model}

We have deliberately refrained from modelling more FDI specificities that -according to the literature- also have an impact on FDI. Examples are

\footnotetext{
${ }^{18}$ The precise values for $Q_{i j}$ depend on which specific PTA index we use.

${ }^{19}$ The current literature (i.e. Dür et al., 2014; Miroudot and Rigo, 2019; Hofmann et al., 2017) finds that there is a host of qualitatively different provisions in trade agreements, implying that there are alternative ways of ranking PTA depth. The PTA-depth databases of Hofmann et al. (2017) and Dür et al. (2014) use depth levels derived from the number of active provisions in a bilateral or multilateral agreement. Another way of interpreting the PTA depth levels is to link it to Balassa's classification of levels of economic integration (Balassa, 1961).

${ }^{20}$ In the empirical section we find that in the DESTA database (Dür et al., 2014) that has a depth range from 0 to 7 , the average PTA depth is 3.7.
} 
the industry differences in foreign investment strategies (market-seeking, resource-seeking, global value chains), biases due to tax routing of FDI (Damgaard et al., 2019), or the firm-level interaction between investment and trade strategies (e.g. Conconi et al., 2016). Such factors may cause additional variance in bilateral FDI patterns. The key in the econometric testing of our model is whether the main policy variables (i.e. PTAs and BITs) remain significant despite the non-modelled, non-observed, or even non-observable impacts on global bilateral FDI patterns. Our model is therefore empirically testable and falsifiable. If, for whatever reason, we do not find the predicted FDI patterns, the model must be rejected. This creates a range of challenges that must be dealt with in the econometric testing of the model:

- Impact factors for bilateral FDI at the level of individual country pairs, known from the literature but not specified in the present model;

- Non-observed or even unknown impact factors that may be relevant at the firm or/or country level;

- Additional country-pair time-varying policy shocks to bilateral FDI. We account for PTAs, BTIs, and EU membership changes, but other policies can have additional impacts;

- Confounding impact factors that affect both the dependent variable (bilateral FDI) and some or all of the explanatory variables (e.g. PTA endogeneity and tax routing of FDI), which may lead to biased econometric results. ${ }^{21}$ There is sufficient empirical evidence that country pairs with large bilateral trade flows are more likely than others to engage in joint preferential trade agreements (cf. Baier and Bergstrand, 2007; Egger et al., 2011). This endogeneity effect of PTA could also hold for bilateral FDI and BITs (cf. Bergstrand and Egger, 2013).

In what follows, we discuss how we deal with these important datarelated and econometric challenges, so that the gravity estimation is neither biased nor inconsistent with its theoretical foundations.

First, in line with the recent literature we employ a Pseudo-Poisson maximum likelihood (PPML) estimator, because it effectively deals with zero bilateral FDI flows and accounts for the presence of heteroskedasticity in FDI data (Santos Silva and Tenreyro, 2006). We are careful to distinguish sharply

\footnotetext{
${ }^{21}$ See Pearl (2009) and Lewbel (2019) for methodological backgrounds.
} 
between real zero FDI (flows or stocks) and missing (or non-reported, suppressed) data. However, the quality of the data on bilateral FDI leaves more uncertainty on this issue than holds for the case of, for instance, bilateral trade.

Second, we also follow the best practice of using country-pair-fixed effects to account for any unobservable time invariant FDI barriers. Using pairfixed effects has been proven to be a better measure of the bilateral costs than the standard set of gravity variables (Egger and Nigai, 2015; Agnosteva et al., 2014). In addition, the standard gravity equation applied to bilateral trade flows points to an endogeneity issue regarding the relation between PTAs and trade. PTAs are more likely between partners that already have intense trade relations. This endogeneity problem will also be present when dealing with FDI flows. Several methods can be used to account for this issue (see for example, Egger et al., 2011; Anderson et al., 2020). In this respect, we follow the common practice of using country-pair fixed effects, which can also deal with the endogeneity of PTAs by accounting for the observable and unobservable linkages between the endogenous trade policy covariate and the error term (Yotov et al., 2016). In addition, the use of only one PTA variable may still give biased results if there are simultaneous other pairwise time-varying factors that could play a role in determining FDI. This is why we combine our PTA indicators with other policy variables such as bilateral investment treaties (BITs).

Third, we use origin-time and destination-time fixed effects to properly account for multilateral resistance terms in panel data gravity estimations (Olivero and Yotov, 2012). The country of origin generates the outward FDI stock and the destination country the inward FDI stock. The origin-time and destination-time fixed effects also absorb the country size variables $\left(Y_{i t}\right.$ and $Y_{j t}$ ) from the structural gravity system in equations (1-3), in addition to all other observable and unobservable time-varying country-specific characteristics, including different national policies, institutions, and exchange rates (Yotov et al., 2016).

Fourth, we use panel data, which leads to improved estimation efficiency, and more importantly, allows the use of the country-pair fixed-effects and the origin-time and destination-time fixed effects methods mentioned above.

Fifth, we must account for the effect of non-discriminatory domestic policies. Even if they are not explicitly discriminating foreign trade and investment, they still are likely to affect the level and pattern of international trade and investment (Kox and Lejour, 2005). To estimate the effects of non-discriminatory policies we follow Heid et al. (2015), which estimate the structural gravity model using both international and intra-national trade 
flows. The same reasoning may apply to FDI flows, and we assume that nondiscriminatory policies also influence domestic capital stocks and inward FDI stocks. Yotov et al. (2016) mention some further reasons why the gravity estimations should include international and intra-national (domestic) data. It provides a theoretically consistent identification of the effects of bilateral policies and a bias-free estimation of the effects of PTAs on FDI. Moreover, it resolves the 'distance puzzle' by accounting for both foreign and domestic distances.

Sixth, since trade (and FDI) flows do not respond immediately to trade policy changes, some authors have criticised the use of panel-data estimations over consecutive years (Trefler, 2004). However, using bilateral FDI stocks as our main dependent variable lessens this concern, since stock data is much less volatile than trade and FDI flows. We test the sensitivity of our results by employing FDI stock data grouped in 2-year, 3-year and 4-year averages. $^{22}$

Seventh and final, there is significant heterogeneity between PTAs (Horn et al., 2010). Thus, using a simple PTA dummy variable could bias the estimated effects of PTAs on FDI flows. Deep PTAs usually include investment provisions and other provisions that might ease FDI inflows, in this might impact a different effect than in shallow PTAs. We apply several PTA depth indicators, which are detailed in Section 4.

\subsection{Main regression equation}

Based on the best practices explained above, the structural model of equations (1) to (3) is then applied to a data panel (with time $t$ ) using the following econometric specification for our baseline regression:

$$
F D I_{i j t}=\exp \left[\gamma_{1} \mathbf{P O L}_{i j t}+\mu_{i t}+\mu_{j t}+\mu_{i j}\right]+\epsilon_{i j t}
$$

where $F D I_{i j t}$ is the inward FDI stock from origin country $i$ to the country of destination $j$ in period $t$. $\mathbf{P O L} i j t$ is a time-variant vector of bilateral policy variables (e.g. PTAs, BITs and EU membership). $\mu_{i t}$ are time-varying origin-country fixed effects (dummy variables) that control for the outward multilateral resistance terms and countries' output shares. $\mu_{j t}$ are timevarying destination-country fixed effects that account for the inward multilateral resistance terms and total expenditure. $\mu_{i j}$ are the set of country-pair fixed effects that absorb all time-invariant gravity covariates from $z_{i j}$ along with any other time-invariant determinants of FDI friction costs that are

\footnotetext{
${ }^{22}$ In the case of FDI flows we do use 4-year averages as our main dependent variable.
} 
not observable. Finally, $\epsilon_{i j t}$ is a combined error term. Equation (4) is our main estimating equation.

There can be several country-specific time-varying policy variables that might also affect bilateral FDI. Therefore, we employ additional policy variables -alternative economic integration indicators, currency unions, BITs, and other policy indices. Using these additional policy variables together with our PTA indicators, allows us to check that the effect of PTAs is not indirectly reflecting the effect of other variables. In addition, by combining several policy variables, we can also identify which additional policy variables might be relevant to explain bilateral FDI values.

As an alternative and to test the robustness of our results, we also use the standard gravity equation:

$$
F D I_{i j t}=\exp \left[\gamma_{1} \mathbf{P O L}_{i j t}+\gamma_{2} \mathbf{C}_{i j}+\mu_{i t}+\mu_{j t}\right]+\epsilon_{i j t}
$$

where $\mathbf{C}_{i j}$ is the vector of time-invariant bilateral control variables (i.e. bilateral distance, contiguity, common language and colonial ties). By including these bilateral time-invariant covariates, we can no longer use the countrypair fixed effects in equation (4). Hence, by comparing both specification, we can observe how important the unobservable and not identified FDI determinants and barriers are to our estimations. ${ }^{23}$

As explained before, we test a partial-equilibrium FDI model, were only the bilateral stocks change after a change in the bilateral policy variables. The time-varying multilateral resistance terms in the gravity model take account of the changes in each country's relative opportunity cost for FDI investing. It is important to stress again that the focus is on the direct effects on FDI. However, a partial analysis cannot capture all knock-on welfare effects of more FDI via domestic consumption prices and production efficiency. For example, if a PTA creates a more integrated market area (via deeper PTAs and FDI inflows) it may also attract more FDI from nonmember countries. These additional effects can only be identified through a general equilibrium analysis, which is beyond the scope of this paper.

\section{Data}

\subsection{FDI bilateral data}

For structural gravity analysis we need bilateral data. Most data sources on FDI only provide inflows or outflows of one country from/to the Rest of

\footnotetext{
${ }^{23}$ In addition, by not using country-pair fixed effects, we can not effectively control for the endogeneity of signing PTAs with existing FDI stocks.
} 
the World. Moreover, the gravity analysis requires the information of the full world FDI matrix -although some simplification is possible by grouping together minor countries/regions. Only a few sources offer consistent time series for bilateral FDI flows. We use UNCTAD's Bilateral FDI Statistics (UNCTAD, 2014), which provides systematic FDI data for over 200 countries, covering inflows, outflows, inward stocks ('instock') and outward FDI stocks ('outstock'). The UNCTAD data is collected mainly from national sources when available. If not, it is complemented with data from partner countries (mirror data) and with data from other international organisations. $^{24}$ The data are available for four FDI categories: inflows, outflows, instock and outstock. This database has available information for the years 2001 to 2012 , and all the data are in US\$ millions. Importantly, the database distinguished between zero flows and missing data, which provides valuable information for our analysis.

Bilateral FDI stocks measure the magnitude of the use that a host country makes of knowledge capital from a particular origin country. ${ }^{25}$ Like Anderson et al. (2020), our dependent variable in the main specification is the inward FDI stock data from UNCTAD, which is also the FDI category with most data availability. When inward stock is missing or zero, we use the 'mirror' outward stock data, if available. As a result our compiled UNCTAD database consists of 203 countries, 12 years (2001 to 2012), around 78 thousand total observations and eight thousand total country-pairs with and average number of observations by country-pair of around nine. There are 26762 zero values, which represent $31 \%$ of the total number of observations.

Note that there is a small proportion (less than $3 \%$ ) of stock values in the UNCTAD database that are negative. This issue can be explained by looking into the three elements included in the FDI flow and stock values:

1. Greenfield direct investments/disinvestments

2. Changes in intra-company loans or leases or franchise fees between holding and subsidiaries

3. Changes in valuation of foreign subsidiaries (either changes in equity

\footnotetext{
${ }^{24}$ For instance, the OECD's International Direct Investment Statistics database and the IMF's FDI data.

${ }^{25}$ As in Anderson et al. (2019, 2020), we use bilateral FDI stock data, which are more widely available and reliable than FDI flow data, and which is close to the knowledge capital stock concept. We use FDI flow data as part of our robustness tests, but because it has a large degree of volatility over time we use 3- and 4-year averages instead of yearly data.
} 
valuation or appreciation/depreciation of real investment stock, or acquisition changes of local minority-owned subsidiaries ( $<10 \%$ owned)

In particular, the last two elements can result in negative flows and even stocks. Using the average data over two, three and four years solves part of this problem. However, since it is not practically or theoretically consistent to have negative FDI stock values, we set the remaining negative values equal to zero. ${ }^{26}$

It is known from the literature that bilateral FDI stocks may be disturbed by tax routing and other measurement issues (Beugelsdijk et al., 2010; Damgaard et al., 2019). Tax routing refers to bilateral FDI that may be 'phantom FDI' traffic, which is attracted either by countries with low tax rates (tax havens), or by countries that facilitate special-purpose-enterprises (letter-box companies) that are frequently used in private or corporate tax evasion. Damgaard et al. (2019) estimate that most of the world's 'phantom' FDI is in a small group of offshore centres: Luxembourg ( $\$ 3.8$ trillion), the Netherlands (\$3.3 trillion), Hong Kong SAR (\$1.1 trillion), British Virgin Islands ( $\$ 0.8$ trillion), Bermuda (\$0.8 trillion), Singapore (\$0.8 trillion) and the Cayman Islands ( $\$ 0.7$ trillion). In recent years, the OECD is asking member states to provide FDI statistics that distinguish between the immediate and the ultimate FDI destination country. However, so-far these data are only available for a small country sample and a few years. In our study we assess the impact of tax routing on inward of FDI stocks by doing separate regressions for country samples with and without the countries that are central in corporate tax evasion. This can only be a rough indicator because countries like The Netherlands, Singapore and Hong Kong are themselves large enough to attract much inward FDI, even without tax facilities.

One or our econometric strategy choices (cf. Section 3.2) is to compare outward FDI with investing in domestic capital stocks. To obtain the domestic capital stock data, we employ the 2019 version of the IMF Investment and Capital Stock Dataset (IMF, 2019). IMF gives these real investment and capital stock series in constant international dollars using constant (2011) PPP exchange rates in order to make the series comparable across countries. These values were converted into current US dollars to make them comparable with the UNCTAD-based FDI data. ${ }^{27}$

\footnotetext{
${ }^{26}$ Negative valuations may be regarded as corrections of the value of FDI stocks of past years, and therefore do not refer to the actual period of time. Negative FDI stocks would also be inconsistent with a gravity model, because a negative FDI stock value could only arise in the case that at least one of both economic masses $\left(Y_{j}, Y_{i}\right)$ is negative.

${ }^{27}$ For this we use the PPP to nominal US\$ conversion factors from the World Development Indicators.
} 


\subsection{The DESTA database}

The main policy variable we analyse is the presence and depth of PTAs. In particular, we use the Design of Trade Agreements (DESTA) database (Dür et al., 2014). This database has systematically collected data on more than 700 agreements, which are then codified to identify the presence of active PTAs for country dyads. It also ranks each PTA by the presence of seven different provisions: full tariff reductions (with few exceptions), provisions on common standards, services trade provisions, competition policy provisions, provisions on public procurement, investment and intellectual property rights (IPRs). Using these provisions DESTA generates a PTA depth index that ranges from one to seven, depending on how many provisions are present in each trade agreement. ${ }^{28}$

The most recent database version (May 2019) covers the time period between 1948 and 2018. ${ }^{29}$ Since many of the initial 'base' agreements have later been modified (by accessions, withdrawals, amendments, consolidations, or are currently under negotiation), there are more than six thousand entries in the database. Since this number refers to unique country pairs, then we have more than one hundred thousand observations when we allow each observation to have its dual country-pair. ${ }^{30}$

Some adjustments have been made to the original DESTA database. The most important one relates to the EU, since DESTA does considers the EU's single market to have a depth index of five. This classification is based on the contents of the European Economic Area agreement, but does not account for other EU-wide non-trade agreements. However, the EU single market provides broader and deeper economic integration than any existing PTA. The EU's single market is the largest project of economic integration among sovereign states. ${ }^{31}$ It's legal and institutional setting assures that the EU single market provides substantially less friction for bilateral trade and FDI than the deepest PTA. Therefore, initially we assume that all EU

\footnotetext{
${ }^{28}$ Note that the DESTA depth indicator is a 'count' indicator but not an accumulative indicator. Hence, any PTA with two provisions, no matter which, will have a depth index of two. Only depth-index seven includes all provisions.

${ }^{29}$ Retrieved from: https://www.designoftradeagreements.org/.

${ }^{30}$ For example, a German-Dutch treaty will only appear as DEU-NLD in DESTA, but we also include its dual observation: NLD-DEU, so it can match are dual country dyads from the FDI database.

${ }^{31}$ Among others, this is provided by the four fundamental principles of single market -free movement of goods, capital, services, and labour, the customs union and common external trade policy, the large number of EU-wide regulatory bodies, and the enforcement of EU law through the European Court of Justice.
} 
country-pairs have the deepest PTA index (with value seven). Nevertheless, our preferred specification is to separately distinguish the EU single market integration institutions, which go well beyond any existing PTA, by using a EU single-market dummy variable (EU-sm). ${ }^{32}$ Two additional adjustments were made. First, each new EU member states automatically inherits the past PTAs negotiated by the EU. Thus, upon the date of accession of each new member state, we adjust the DESTA data to reflect that these new member countries also are part of the previously negotiated EU PTAs. Second, we correct the initial year of implementation for some treaties (i.e. the Pacific Alliance, the Central America PTA and the EU-Central America Association Agreement).

At the most general level, we use DESTA database to identify the presence of a PTA by using a dummy variable that is one if two countries in a particular year are both members of the same PTA, and zero otherwise. Next to that we employ the DESTA depth index as our main PTA depth indicator. ${ }^{33}$ Finally, we also make dummy indices for each of the seven provisions in the DESTA depth index, so that we can isolate which PTA component is more important to explain FDI inflows.

Combining the UNCTAD bilateral FDI data with the DESTA database provides us with more than one hundred thousand observations: around 8500 unique country-pairs for 12 years (2001-2012). As has been previously documented (Dür et al., 2014; Miroudot and Rigo, 2019), the cumulative number of active PTAs, as well as the depth of PTAs has been increasing over time. For our sample period, Figure 1 shows an increase in the share of active PTAs (from around $28 \%$ of total observations in 2001, to $40 \%$ in 2012). We also observe that the PTA depth has experienced a less pronounced increase, moving from a depth average of 3.6 in 2001 to 3.9 at the end of the time interval.

- FIGURE 1 around here -

The DESTA depth index is a count index and the depth-levels one to six may have different combinations of provisions. Table 1 shows the frequency of different PTA depth combinations. First, we observe that around onethird of all observations (and of all country-pairs) have an active PTAs

\footnotetext{
${ }^{32}$ We account for the year of accession of new member states: 2004 for ten new members states, 2007 for Bulgaria and Romania, and 2014 for Croatia.

${ }^{33}$ When there is no DESTA information for a country dyad, or the treaty is not yet implemented we then assign a value of zero to both the PTA dummy and the depth indicator.
} 
during this period. When there is an active PTA, the most common depth levels are one and seven (both with around $28 \%$ of total observations). When we look at country-pairs, however, the most common depth level is seven (29\%), but this is driven by EU member states, since country-pairs within the EU single market represent $21 \%$ of the total PTAs. Once we disregard the country pairs in the EU single market, the most common depth level is three (24\%). The EU, moreover, is part of 2263 observations with an active PTA (as at least one of the partners) and this represents $68 \%$ of all the active PTAs during this period. Once excluding the country-pairs within the EU single market, the most frequent depth levels for EU trade agreements are three $(30 \%)$ and seven $(20 \%)$.

— TABLE 1 around here —

Finally, we look at the individual provisions that constitute the DESTA depth index. We find that the standards provisions is the most common, present in $88 \%$ of all PTAs, followed by full tariff reductions (73\%). The services, public procurement and competition provisions are present in around half the PTAs, while the least common provisions are on IPRs (34\%) and investment (39\%). Table A.1 in the Appendix shows the most frequent provision combinations by PTA depth level. There we observe that when only one provision is present (depth 1), the standards provisions accounts for $70 \%$ of the cases, with the full tariff reductions accounting for $23 \%$. Since these two provisions are the most common, it is not surprising that for PTAs with two provisions, this combination (standards + full tariffs) accounts for $95 \%$ of the cases. However, when three provisions are present, the most common combination does not include them, and the combination with services, competition and investment represents $29 \%$ of the cases. For PTAs with depth level four, the most common combination is standards, full tariffs, services and competition (80\%). For PTA depth levels of five and six, the most common combinations exclude IPRs, which is also the least common of all the provisions.

\subsection{Additional policy variables}

In this section we describe additional policy variables that are used to complement the DESTA database and test the sensitivity of our results. Hence, apart from the widely used DESTA database, we also use the most recent World Bank PTA depth database (Hofmann et al., 2017), and WTO's Regional Trade Agreements Database that is built on official notifications by 
member governments. ${ }^{34}$

\subsubsection{World Bank horizontal depth PTA database}

The World Bank (Hofmann et al., 2017) has also compiled a database that includes 279 preferential trade agreements (PTAs) signed by 189 countries and reported to the WTO between 1958 and 2015. The database builds on the methodology developed by Horn et al. (2010). It explicitly reports if each PTA includes any of up to 52 provisions on different policy areas and the legal enforceability of each provision. In total, the database provides information over 104 variables (52 provisions and, separately, their legal enforceability).

Some of these provisions relate to policy areas that fall under the current mandate of the WTO -referred to as 'WTO plus' ('WTO+') in the literature. This includes topics related to anti-dumping measures, export taxes, customs regulations, technical barriers to trade (TBT) and sanitary and phytosanitary standards (SPS). It also reports provisions outside the WTO mandate -i.e. 'WTO extra' or 'WTO-X' - which includes a wider range of policy areas, such as investment provisions and environmental standards. This rich source of information allows the construction of different PTA depth indexes. Some are based on the type of provision (WTO+, or WTO$\mathrm{X}$ ). Others use the concept of 'core' provisions (e.g. Baldwin, 2008; Damuri, 2012), which are considered to be the more significant or 'core' provisions from an economic point of view. These include all the WTO+ provisions, in addition to four WTO-X provisions (competition policy, investment, movement of capital, and intellectual property rights protection).

To account for the depth of a PTA using the World Bank database we use four indexes, which are based on the three original indexes developed in Hofmann et al. (2017), plus an additional index:

- The first two indexes are the 'total depth' indexes, which are the simple count of legally enforceable provisions included in a PTA (defined as $\left.w b \_t o t \_l e\right)$ and the simple count of the 52 provisions ( $\left.w b \_t o t \_p r\right)$. The first was originally included in Hofmann et al. (2017) and we construct the second index for robustness purposes.

- The 'core depth' variable (wb_core), which follows and counts the total number of 'core' provisions that are included and legally enforceable in a PTA.

\footnotetext{
${ }^{34}$ Retrievable from ww.rtais.wto.org.
} 
- The 'PCA depth' index ( $\left.w b \_p c a\right)$ based on a principal-component analysis (PCA) to obtain an index for the variability in the data.

Finally, we also create a dummy variable for the presence of a PTA $\left(P T A_{w} b\right)$, with the value of one for those dyads where a PTA is present in the World Bank database.

\subsubsection{Additional economic integration indicators}

The WTO's Regional Trade Agreements Database is based on official member state notifications. ${ }^{35}$ The WTO database is not in dyadic form, but it has been converted to a dyadic form by some researchers, inter alia Mario Larch Egger and Larch (2008), with an update in 2017. We use the latter as an alternative source of PTA classification and as additional bilateral time-variant policy indicators. In particular, Mario Larch's database distinguishes between different degrees of trade integration: partial scope agreements (PS), free-trade agreements (FTA), customs unions (CU) and economic integration agreements (EIA). With two indicators that combine these variables: CU and EIA, and FTA and EIA. Moreover Larch adds a dummy indicator (RTA), which is equal to one if any one of PS, FTA, CU or EIA is in place, and zero otherwise.

We also employ an indicator (dummy) variable for the existence of a bilateral investment treaties (BITs) from the original UNCTAD data on international investment agreements (UNCTAD, 2019). Moreover, we distinguish between BITs that have been signed and those that are effectively in force. ${ }^{36}$ This provides additional depth to our analysis, and allows us to test how important it is to legally enforce BITs to incentivise bilateral.

Finally, we link the FDI database with the CEPII database (Head et al., 2010) to obtain additional control variables - to be used in the traditional gravity regressions. These include variables such as distance, contiguity, language, colonial past, and other dyadic variables. ${ }^{37}$

The simple correlations between the bilateral FDI stocks, the DESTA PTA indicators and the additional policy variables are presented in Table

\footnotetext{
${ }^{35}$ It distinguishes between: free trade agreements (as defined in Paragraph 8b of Article XXIV of GATT 1994), partial scope agreements (not defined in the WTO Agreement, but notified under paragraph 4a of the Enabling Clause), custom unions (as defined in Paragraph 8a of Article XXIV of GATT 1994), economic integration agreements (as defined in Article $\mathrm{V}$ of GATS).

${ }^{36}$ We want to thank Valentino Desilvestro for sharing these data with us.

${ }^{37} \mathrm{We}$ also use the average population-weighted domestic distances for those cases where the origin and destination are the same.
} 
A.2 in the Appendix. It is interesting to observe that the correlation between the DESTA PTA dummy and depth indicators and the other PTA indicators (i.e. from the World Bank and WTO databases) are relatively high, with values ranging between 0.65 and 0.85 . However, the correlations are not as high as to convene the same underlying information and thus, it provides a good robustness tests to our main results using the DESTA database.

\section{$5 \quad$ FDI gravity results}

In this section we present our main empirical results based on the FDI gravity model defined in Equation 1 using yearly bilateral FDI stock data and the PTA indicators taken from the DESTA database.

\subsection{Main results}

In Table 2 we present the results of our preferred econometric specification using country-pair fixed effects (Equation 4). ${ }^{38}$ Given the high correlation between the PTA dummy and the PTA depth indicators (0.8) in Table A.2, we do not regress both variables together. We observe that the DESTA depth index has a positive and significant effect on inward FDI stocks, while the PTA dummy variable (constructed using the DESTA database) is also positive and significant. ${ }^{39}$ Moreover, the inclusion of a dummy variable to identify country-pairs within the EU single-market, is also positive and significant, and the magnitude of its effect is substantially larger than both of the PTA indicators. The regressions reported in Table 2 use clustered standard errors by country pair, but the results appeared to robust to different error specifications: robust standard errors, using the three-way (origin, destination and time) clustering option for standard errors. ${ }^{40}$

— TABLE 2 around here -

In columns (5) and (6) of Table 2 we give the results of the specification using the traditional gravity variables, where $l n \_D I S T$ is the log of the weighted distance indicator, $C N T G$ is the contiguity dummy for countries

\footnotetext{
${ }^{38}$ To estimate the PPML regressions we use Zylkin's STATA ado files (cf. Larch et al., 2017), which provide a much faster estimation than the normal STATA command.

${ }^{39}$ Note that as shown by Fally (2015), using PPML in conjunction with country-time and country-pair fixed effects generates a near-perfect fit of the data (i.e. $R^{2}=1$ ). Thus, this statistic is non-informative for our PPML estimates and we do not report it in any of our regression results.

${ }^{40}$ The results of these robustness checks are available at request.
} 
that share a common border, $L A N G$ is the shared language dummy and $C L N Y$ is the dummy that identifies a common coloniser after 1945. Here we find that these variables have the expected sign, and both the PTA depth and PTA dummy variables are again positive and significant, but with much higher coefficient values. These last results suggests that not controlling for non-observable time-invariant factors -as done when we use the countrypair fixed effects in columns (1) to (4), over-estimates the impact of PTAs on FDI flows. Hence, the country-pair fixed effect specification provides more accurate estimated coefficients of the impact of PTAs on inward FDI stocks.

The robustness of our results with this baseline regression was tested by three variants that we show in Appendix A.2 (see Tables A.3 to A.5). In these tables, the dependent variable is defined by, respectively, 2-year, 3-year and 4-year averages to check for the (Trefler, 2004) critique regarding the implementation time of PTAs. In all specifications, however, the sign and significance of our main explanatory variables is retained.

To facilitate the interpretation of the estimated regression parameters for the policy variables using the PTA dummy and depth indicators from DESTA, we translate them in a percentage effect on the dependent variable (inward FDI), using the following formula:

$$
V=\left(e x p^{\hat{\gamma}}-1\right) * 100
$$

where $V$ is the FDI effect (in percentages) of each individual indicator, with $\hat{\gamma}$ being the estimated coefficient by indicator. In Table 3 we present the result for the PTA indicators when different depth values are used. Recall that the DESTA database is ranked from one (shallow PTA) to seven (deepest PTA). For instance, the implementation of the deepest PTA is estimated to increase the bilateral inward FDI stock of the host country by approximately $35 \%$, while a shallow PTA (with DESTA index of one) will only increase bilateral FDI by $4 \%$.

— TABLE 3 around here -

However, the average estimated effect on bilateral FDI stocks of signing a PTA is $31 \%$ when only a PTA dummy variable is used. This implies that just signing a PTA, regardless of its depth, has a larger impact than signing a PTA with a depth level below seven. In particular, much of the impact of deep PTAs is driven by countries that belong to the EU single market. The EU members account for around $70 \%$ of PTAs that will otherwise be identified as 'deep' (with a DESTA index of seven). Hence, given that the 
EU single-market entails a much deeper integration than a PTA, we find that it is crucial to include the EU single market dummy in our regressions.

This finding (depth of the PTA has no substantially different effect than just signing a PTA) is corroborated when we regress independently each PTA depth level and each PTA provision. These results are shown in Table 4. First, we observe that most depth levels are not significant when regressed individually. Only PTAs with depth three and five have significant effects, but they are well below the average impact of signing a PTA of any depth. Moreover, PTAs of depth seven are only significant when the EU single market is taken as a deep PTA.

— TABLE 4 around here -

On the other hand, when we individually regress each of the seven provisions that constitute the DESTA depth index, we find that all provisions are positive and significant. Moreover, the expected FDI effect of five of those provisions ranges between 20 and 30\%. Including IPR provisions has the largest FDI effect (37\%) and, remarkably, PTAs with investment provisions generate the lowest FDI impact (15\%). That all provisions are significant, and with relatively similar estimated coefficients, suggests that no particular provision is responsible for promoting bilateral FDI. In addition, given the inconclusive results by individual PTA depth levels, this also suggests that the main factor generating additional bilateral FDI is the presence of a PTA, irrespective of which provisions it includes.

When we frame these results with respect to our empirically testable hypothesis, we find that the first two hypothesis are confirmed. Both the presence of a PTA and the PTA depth index are increasing bilateral FDI, through an increase in FDI openness and/or by reducing relative FDI friction

costs. However, our results reject the third testable hypothesis that deeper PTAs (above the average of 3.7) have a statistically higher effect than just signing an average depth PTA.

\subsection{Assessing the FDI impact of BITs}

We now analyse the impact of additional country-pair policy time-varying indicators. First, we estimate the impact of having a bilateral investment treaty (BIT). As explained before, we distinguish between signed BITs and those that, in addition, are also in force.

Table 5 shows that BITs have a positive and significant impact on bilateral FDI. When alone or in combination with the PTA indicators and/or 
the EU single market dummy, both signed and BITs and in-force BITs have a higher effect than signing a PTA. As expected, BITs that are in force have a higher impact -around $42 \%$ increase in bilateral FDI- than those that are only signed (around 35\%).

- TABLE 5 around here -

Moreover, the estimated impact values for the BITs and the PTA coefficients are quite similar when they are combined in the same regression. This suggests that PTAs and BITs affect different FDI barriers, and thus, have separate but positive effects on bilateral FDI. This is further confirmed by the rather low correlations between the BITs and PTA indicators, at around 0.15 (see Table A.2). By construction, the BITs are different from trade agreements and, moreover, they also signal country-specific FDI investment risks. BITs are set to guarantee private investments from one country into another by means of different instruments, such as protection from expropriation, free transfer of means, fair and equitable treatment, foreign investors fair and equitable, non-discriminatory, most-favoured-nation and national treatment, and sometimes the use of investor-state dispute settlement (ISDS) mechanisms (cf. UNCTAD, 2007). In this regard, a core objective of BITs is to reduce the investment risks of FDI by establishing transparency about what those risks are in a particular country (Bergstrand and Egger, 2013). BITs are more likely to be established when countries want to protect firms investing in countries that are considered to be risky. Such motivation is hardly required for protecting North-North investment, when the national legal systems usually provide enough protection for firms with FDI. For example, the USA had BIT agreements with many Eastern European countries before their EU accession, but do not have BITs with their main trading partners (e.g. old EU members, Canada, China, Japan and Mexico.)

These positive results regarding the effect of BITs have been also found in (e.g. Bergstrand and Egger, 2013). Our results, however, do not support the claim by Haftel (2010) that only BITs in force (i.e. mutually ratified)

would have a positive effect on FDI inflows, whereas agreements that are not in force (only signed) would have little effect.

\subsection{Estimating the FDI impact of other economic integration indicators}

In this section we run a second set of regressions using alternative countrypair time-varying policy instruments. Table 6 shows our regression re- 
sults when using the economic integration indicators taken from the WTO database. ${ }^{41}$

— TABLE 6 around here -

We find the presence of a free trade agreement ('FTA' in Table 6) has a positive and significant effect on FDI inflows. However, the magnitude of the effect is lower than using the PTA DESTA dummy variable. In general, we find that all economic integration indicators are positive and significant. However, the most interesting result is that the customs union (CU) indicator has by far the largest effect (93\%), also when it is combined with a free trade agreement $(98 \%)$. On the other hand, it is surprising that the partial scope (PS) has a larger effect than the FTA.

Nevertheless, these results seem to be conditional on the treatment of the EU single market. As we mentioned before, membership to the EU single market entitles a broad set of common policies that when taken together, represent deep integration mechanisms. Hence, even though the EU can be separately qualified as a customs union, a trade agreement and an economic integration agreement, in reality it encompasses all three elements. In reality is also includes other institutions -such as shared regulations and the legal superposition of European Court of Justice- that makes it puts it in a much deeper integration level than the WTO-based classifications. In this regard, when treating the EU only as a customs union, the estimated coefficient can be biased given that the EU single market also accounts for other integration policies.

Based on this we run a separate set of regressions where we separately account for the EU single market. These results are shown on the bottomhalf of Table 6 . We find that controlling for the EU single market, the CU indicator is no longer significant. The previous results was clearly driven by accounting EU membership solely as a customs union, where two-thirds of the CU observations where EU country-pairs. However, the other integration indicators remain significant. Even the CU \& EIA indicator, even though $94 \%$ of the observations for this indicator where EU country-pairs.

\section{Sensitivity estimations}

To analyse the robustness of our results to different specification, we run a series of sensitivity tests, which are explained below. Note however, that we

\footnotetext{
${ }^{41}$ The definition and construction of these indicators is explained in Section 4.3.2.
} 
already ran some sensitivity analysis. First, using different yearly averages for inward FDI (2-year, 3-year and 4-year averages) and second, we employed different standard error specifications in the PPML regressions.

\subsection{Using the World Bank's depth indicators}

In Table A.6 in Appendix A.2 we present the regression results using the constructed PTA indicators from the World Bank PTA depth database (Hofmann et al., 2017). We find that all these PTA indicators are significant when we use the country-pair fixed effect specification and also when we identify country-pairs that belong to the EU single market. Thus, we find that PTAs and different combinations of the 52 provisions included in the World Bank database also generate positive and significant bilateral FDI effects.

The level of detail in this database - which includes 52 provisions that also vary by legal enforceability- makes it non-practical to do detailed provisionspecific analysis. It is also difficult to identify an 'average' PTA depth for testing our third hypothesis -i.e. deep PTAs have a larger impact than average PTAs. To approximate some average PTA depth we use the 'core depth' variable ( $w b$ _core) that counts the total number of 'core' provisions that are included and legally enforceable in a PTA. We compare its impact on bilateral FDI with that of a simple PTA dummy for the presence of a PTA (also based on the same database). The conclusion is that the estimated impact of the PTA dummy is much larger than the estimated impact of the $w b \_c o r e$ indicator. Remarkably, because it suggests that just signing a PTA (irrespective of the number of provisions) has a much larger effect than including what are considered the 'core' provisions in PTAs. Hence, this result also reinforces our conclusion that the presence of a PTA has the same or similar effects than signing a 'deep' PTA. ${ }^{42}$

\subsection{Excluding domestic stocks}

We estimate our main specifications excluding the 'domestic inward' stocks taken as the country's capital stock data. Recall that we used this specification in our main estimations because of the large relative weight of domestic (versus border-crossing) investment, which suggests that barriers to border-crossing FDI are very important. It is therefore interesting to know

\footnotetext{
${ }^{42}$ The same results hold (cf. A.6) for the comparison with other depth indices (e.g. $w b \_t o t \_p r$ and $\left.w b \_p c a\right)$.
} 
what happens when these large relative weights in the world FDI matrix are dropped.

In Table A.7 in the Appendix we present the results. As expected, we find that the coefficients from the structural gravity equations are completely different from those obtained when we control for the domestic investment stocks. Importantly, we observe that the PTA and the BITs indicators are no longer significant using this specification, while the PTA indicators now have a negative sign. Only the EU single market dummy remains positive and significant. ${ }^{43}$

These results highlight the importance of controlling for domestic capital stocks in the gravity estimations as explained in the best-practices taken from Yotov et al. (2016). In particular, using domestic capital stocks we can control for the effects of non-discriminatory trade policy, allow for consistently identifying the effects of PTAs and other bilateral trade policies, and obtain a bias-free estimation of the effects of PTAs on FDI inward stocks.

\subsection{Excluding tax havens}

As explained above, bilateral FDI data is fraught with measurement and compilation issues. One of these problems is created by tax havens and countries that re-route FDI flows (cf. Beugelsdijk et al., 2010; Damgaard et al., 2019). In this section we test the robustness of our main results by excluding these countries from our sample. In particular, we exclude the following countries: Bahamas, Barbados, Bermuda, Cayman Island, Cyprus, Hong Kong, Ireland, Luxembourg, Netherlands, Netherlands Antilles, Panama, Singapore, and British Virgin Islands. The results excluding these countries from our sample are presented in Table A.8. We find that compared to our main specification, the results are less robust. The PTA depth index is no longer significant, but the presence of a PTA remain significant and positive, although with a lower coefficient. Moreover, the EU single market and BITs that are in force also remain significant.

It can be argued that some of these countries -although they might be creating measurement issues with the FDI data- can also be considered as genuine FDI destinations. For instance, when we do not exclude Hong Kong and Singapore from the main sample, the PTA depth coefficient becomes significant and the value of the PTA dummy coefficient increases to a level similar to the one in our main specification. Therefore, excluding these two countries confirms that the PTA depth indicator is not robust, but our other

\footnotetext{
${ }^{43}$ The results are very similar when using other combinations between the PTA indicators, the EU single market and both BIT indicators.
} 
variables -the presence of a PTA, the EU single market and the presence of enforceable BITs- do remain significant and robust.

\subsection{Using FDI flow data instead of stock data}

The UNCTAD Bilateral FDI database also provides data on FDI inflows and outflows. ${ }^{44}$ We then use these FDI inflow data in our main econometric specification using the yearly data but also average FDI inflows for 3- and 4- year periods. We find that the PTA indicators are only significant when using the 4-year average FDI inflows. The results are shown in Table A.9 in the Appendix. Overall, the EU single market dummy is positive and significant, and the BITs that are in force are significant in the yearly data and the 4-year averages, but not with 3-year averages. However, the BITs that are only signed, are not significant using any of these specifications (results not shown).

These results can be explained by the large volatility of FDI flows, which may fluctuate substantially between years. In addition, the incidence of negative values for FDI inflows is more pronounced than for FDI inward stocks: $13 \%$ of the FDI flow data has negative values. Thus, only using averages of several years can smooth these FDI inflow fluctuations and partially correct for the negative FDI flow values. However, when using multi-year averages, there is an additional complication regarding the exact timing of the shock and how it affects FDI. As we see in the next section, there are significant lags and lead effects, and this complicates the identification of the policy shock when using multi-year FDI averages.

\subsection{PTA dynamics: role of leads and lags}

As the last sensitivity test, we run our main specification using lagged and lead values for our PTA indicators. The intuition is that the specific impact of an PTA can happen some years before or after the agreement enters into force. In other words, signing the PTA can have anticipatory or lagged effects on bilateral FDI. Table A.10 in the Appendix presents the results when we run our main specification using one to three lags and one to three leads (forward in time). In all regressions we include the EU single market dummy.

\footnotetext{
${ }^{44}$ When using FDI flows as our dependent variable, we then employ the World Bank's WDI data on gross fixed capital formation (GFKF) to account for the domestic investment flows.
} 
We find that a PTA has an effect on inward FDI stocks already three years before and up-to three years after signing the agreement. In particular, all our lagged and lead variables yield a positive and significant coefficient for both the PTA dummy and the PTA depth variable. We obtain the same results when we use the PTA dummy variable. The effects are of a similar magnitude but slightly higher one year before (L1) and one year after (F1) the PTA has been implemented. This suggests the presence of both an anticipatory and a lagged FDI adjustments to PTAs.

\section{Conclusions}

Our structural gravity methodology allows us to estimate the expected changes in bilateral FDI by looking into the past experience for similar PTA treaties and other country-pair policies. To account for the heterogenous nature of PTAs, we rely on several PTA indicators but our main results employ the DESTA database. The first contribution of our paper is that we find robust empirical evidence that implementing a PTA has a positive effect on FDI inflows and inward stocks, even when the primary purpose of such agreements is to increase bilateral trade between the signing partners. These results are thus reflecting the increased importance of vertical FDI associated with the trade-FDI networks in global value chains, where trade and FDI complement and are positively correlated with each other.

We also find that the composition of the PTA agreement - proxied by the presence of different provisions- is not empirically important when accounting for the PTA effects on bilateral FDI. For instance, when all provisions included in the DESTA PTA depth index -full tariff reduction, standards, services, competition, procurement, investment and IPRs- are individually regressed, we find that all have positive and significant effects on bilateral FDI. Thus, combining specific provisions in a PTA does not generate significantly different FDI changes. Surprisingly, the investment provision has the lowest impact of all.

In addition, even though we find that the coefficient of the PTA depth index is positive and significant, we also find that the effect of deeper PTAs is not robust. For example, when each PTA depth level is regressed individually, only two out of the seven depth levels are significant. In particular, we find it crucial to control for membership of the EU single market and not classifying these country-pairs has having a deep PTA. Indeed, the European single market entails a much deeper and comprehensive framework for economic integration, which we find to have a substantially higher ef- 
fect on bilateral FDI (i.e. 135\%) than any average trade agreement (31\%). Moreover, we also find that the presence of a BIT also has a positive and significant effect on bilateral FDI. Those BITs that are legally in force have a larger effect, but even BITs that are signed but not enforced also have an effect that is similar in magnitude to that of signing a PTA.

Our main results are robust to the use of different policy variables and empirical specifications. For instance, when employing alternative PTA databases and integration policy indicators, lagged and lead effects, and when excluding countries considered to be tax havens.

Last but not least, the empirical results of this paper are in line with what could be expected on the basis of our partial-equilibrium model for explaining bilateral FDI. Therefore, we think that our model meets the challenge framed by Blonigen (2005) and can function as a valuable new tool for empirical analysis of FDI. Moreover, the empirical results of this model can by used as valuable inputs for larger applied general equilibrium models that assess welfare issues related to FDI. 


\section{References}

Agnosteva, D., J. E. Anderson, and Y. V. Yotov (2014). "Intra-National Trade Costs: Measures and Aggregation," NBER Working Paper 19872, National Bureau of Economic Research.

Alfaro, L. and A. Charlton (2009). "Intra-Industry Foreign Direct Investment," American Economic Review, 99(5): 2096-2119.

Allen, T., C. Arkolakis, and Y. Takahashi (2020). "Universal gravity," Journal of Political Economy, 128(2): 393-433.

Anderson, J. E., M. Larch, and Y. V. Yotov (2019). "Trade and investment in the global economy: A multi-country dynamic analysis," European Economic Review, 120: 103311.

Anderson, J. E., M. Larch, and Y. V. Yotov (2020). "Transitional growth and trade with frictions: A structural estimation framework," The Economic Journal, Forthcoming, doi.org/10.1093/ej/ueaa020.

Anderson, J. E. and E. van Wincoop (2003). "Gravity with Gravitas: A Solution to the Border Puzzle," American Economic Review, 93(1): 170192.

Arkolakis, C., N. Ramondo, A. Rodríguez-Clare, and S. Yeaple (2018). "Innovation and production in the global economy," American Economic Review, 108(8): 2128-2173.

Baier, S. L. and J. H. Bergstrand (2007). "Do Free Trade Agreements Actually Increase Members' International Trade?" Journal of International Economics, 71(1): 72-95.

Balassa, B. (1961). The theory of economic integration, Routledge, routledge reprint 2013 ed.

Baldwin, R. (2008). "Big-Think Regionalism: A Critical Survey," NBER Working Paper 14056, National Bureau for Economic Research, Cambridge, MA.

Baldwin, R. and T. Okubo (2014). "Networked FDI: Sales and Sourcing Patterns of Japanese Foreign Affiliates," The World Economy, 37(8): 10511080 . 
Bergstrand, J. H. and P. Egger (2007). "A knowledge-and-physical-capital model of international trade flows, foreign direct investment, and multinational enterprises," Journal of International Economics, 73(2): 278-308.

Bergstrand, J. H. and P. Egger (2010). "A general equilibrium theory for estimating gravity equations of bilateral FDI, final goods trade, and intermediate trade flows," in The Gravity Model in International Trade: Advances and Applications, ed. by P. V. Bergeijk and S. Brakman, Cambridge, UK: Cambridge University Press, 29-70.

Bergstrand, J. H. and P. Egger (2013). "What determines BITs?" Journal of International Economics, 90(1): 107-122.

Beugelsdijk, S., J.-F. Hennart, A. Slangen, and R. Smeets (2010). "Why and how FDI stocks are a biased measure of MNE affiliate activity," Journal of International Business Studies, 41(9): 1444-1459.

Blonigen, B. (2005). "A Review of the Empirical Literature on FDI Determinants," Atlantic Economic Journal, 33(4): 383-403.

Braconier, H., P. J. Norback, and D. Urban (2005). "Reconciling the evidence on the knowledge-capital model," Review of International Economics, 13(4): 770-786.

Brainard, S. L. (1997). "An empirical assessment of the proximityconcentration tradeoff between multinational sales and trade," American Economic Review, 87(4): 520-544.

Chen, M. X. (2009). "Regional economic integration and geographic concentration of multinational firms," European Economic Review, 53(3): 355375 .

Conconi, P., A. Sapir, and M. Zanardi (2016). "The internationalization process of firms: From exports to FDI," Journal of International Economics, 99: $16-30$.

Damgaard, J., T. Elkjaer, and N. Johannesen (2019). "What is real and what is not in the global FDI network?" IMF Working Paper WP/19/274, International Monetary Fund, Statistics Department, Washington DC.

Damuri, Y. R. (2012). "21st Century Regionalism and Production Sharing Practice," Working Paper CTEI-2012-4, Center for Trade and Economic Integration. 
Daude, C., E. Levy Yeyati, and E. Stein (2003). "Regional integration and the location of FDI," Working Paper 492, Inter-American Development Bank, Research Department, Washington D.C.

Davies, R. and H. Kristjansdottir (2010). "Fixed costs, foreign direct investment, and gravity with zeros," Review of International Economics, 18(1): $47-62$.

Dür, A., L. Baccini, and M. Elsig (2014). "The Design of International Trade Agreements: Introducing a New Database," Review of International Organizations, 9(3): 353-375.

Egger, P., M. Larch, K. E. Staub, and R. Winkelmann (2011). "The Trade Effects of Endogenous Preferential Trade Agreements," American Economic Journal: Economic Policy, 3(3): 113-143.

Egger, P. and S. Nigai (2015). "Structural Gravity with Dummies Only: Constrained ANOVA-Type Estimation of Gravity Models," Journal of International Economics, 97(1): 86-99.

Egger, P. and M. Pfaffermayr (2004). "The impact of bilateral investment treaties on foreign direct investment," Journal of Comparative Economics, 32(4): 788-804.

Egger, P. H. and M. Larch (2008). "Interdependent Preferential Trade Agreement Memberships: An Empirical Analysis," Journal of International Economics, 76(2): 384-399.

Ekholm, K., R. Forslid, and J. R. Markusen (2007). "Export-platform foreign direct investment," Journal of the European Economic Association, 5(4): $776-795$.

Fally, T. (2015). "Structural Gravity and Fixed Effects," Journal of International Economics, 97(1): 76-85.

Haftel, Y. Z. (2010). "Ratification Counts: US Investment Treaties and FDI Flows into Developing Countries," Review of International Political Economy, 17: 348-377.

Hanson, G., R. Mataloni, and M. Slaughter (2005). "Vertical production networks in multinational firms," Review of Economics and Statistics, 87(4): 664-678. 
Head, K. and T. Mayer (2014). "Gravity Equations: Workhorse, Toolkit, and Cookbook," in Handbook of International Economics, ed. by G. Gopinath, E. Helpman, and K. Rogoff, Elsevier, vol. 4, 131-195.

Head, K., T. Mayer, and J. Ries (2010). "The Erosion of Colonial Trade Linkages after Independence," Journal of International Economics, 81(1): $1-14$.

Heid, B., M. Larch, and Y. V. Yotov (2015). "A Simple Method to Estimate the Effects of Non-discriminatory Trade Policy within Structural Gravity Models," Mimeo, University of Bayreuth.

Hofmann, C., A. Osnago, and M. Ruta (2017). "Horizontal Depth: A New Database on the Content of Preferential Trade Agreements," Policy Research Working Paper 7981, World Bank, Trade and Competitiveness Global Practice Group.

Horn, H., P. C. Mavroidis, and A. Sapir (2010). "Beyond the WTO? An Anatomy of EU and US Preferential Trade Agreements," The World Economy, 33(11): 1565-1588.

IMF (2003). "Foreign Direct Investment Trends and Statistics," Working Paper October, International Monetary Fund, Statistics Department.

IMF (2019). "Investment and capital stock dataset: 1960-2017," Version August-2019, International Monetary Fund, Fiscal Affairs Department.

Kleinert, J. and F. Toubal (2010). "Gravity for FDI," Review of International Economics, 18(1): 1-13.

Kox, H. L. M. (2018). "Foreign investment access and the services industry: Quantitative policy analysis for the Philippines," Study commissioned by the International Finance Corporation (World Bank Group), KVL Economic Policy Research.

Kox, H. L. M. and A. Lejour (2005). "Regulatory Heterogeneity as Obstacle for International Services Trade," CPB Discussion Paper 49, CPB Netherlands Bureau for Economic Policy Analysis, The Hague.

Kox, H. L. M. and H. Rojas-Romagosa (2018). "Potential FDI effects of the Pacific Alliance: Results of gravity analysis with bilateral FDI data," Background study commissioned by the International Finance Corporation (World Bank Group), KVL Economic Policy Research. 
Kox, H. L. M. and H. Rojas-Romagosa (2019). "Gravity estimations with FDI bilateral data: Potential FDI effects of deep preferential trade agreements," EUI Working Paper RSCAS 2019/70, Robert Schuman Centre for Advanced Studies, European University Institute.

Larch, M., J. Wanner, Y. V. Yotov, and T. Zylkin (2017). "The Currency Union Effect: A PPML Re-assessment with High-dimensional Fixed Effects," Working Paper 2017-07, Drexel University School of Economics.

Lewbel, A. (2019). "The identification zoo: Meanings of identification in econometrics," Journal of Economic Literature, 57(4): 835-903.

Markusen, J. (2002). Multinational Firms and the Theory of International Trade, Cambridge, MA: The MIT Press.

McGrattan, E. and E. Prescott (2009). "Openess, Technology Capital and Development," Journal of Economic Theory, 100(4): 1493-1522.

McGrattan, E. and E. Prescott (2010). "Technology Capital and the US Current Account," American Economic Review, 144(6): 2454-2476.

Miroudot, S. and D. Rigo (2019). "Preferential trade agreements and multinational production," RSCAS Working Papers 2019/14, European University Institute, Robert Schuman Centre for Advanced Studies, Global Governance Programme.

Olivero, M. and Y. V. Yotov (2012). "Dynamic Gravity: Endogenous Country Size and Asset Accumulation," Canadian Journal of Economics, 45(1): 64-92.

Osnago, A., N. Rocha, and M. Ruta (2017). "Do deep trade agreements boost vertical FDI?" World Bank Economic Review, 30: S119-S125.

Pearl, J. (2009). Causality: Models, reasoning and interference,, Cambridge, UK: Cambridge University Press, second ed.

Ramondo, N. and A. Rodríguez-Clare (2013). "Trade, multinational production, and the gains from openness," Journal of Political Economy, 121(2): $273-322$.

Santos Silva, J. and S. Tenreyro (2006). "The Log of Gravity," Review of Economics and Statistics, 88(4): 641-658.

Trefler, D. (2004). "The Long and the Short of the Canada-U.S. Free Trade Agreement," American Economic Review, 94(4): 870-895. 
UNCTAD (2007). "Bilateral investment treaties 1995-2006: Trends in investment rulemaking," Report UNCTAD/ITE/IIT/2006/5, United Nations Conference on Trade and Development (UNCTAD), New York.

UNCTAD (2014). "Bilateral FDI statistics 2014," Database accessed in August 2018, United Nations Conference on Trade and Development, http://unctad.org/en/Pages/DIAE/FDI\%20Statistics/ FDI-Statistics-Bilateral.aspx.

UNCTAD (2019). "International investment agreements navigator," Investment Policy Hub, database accessed in July 2019, United Nations Conference on Trade and Development, https://investmentpolicy.unctad. org.

Yeaple, S. (2003). "The complex integration strategies of multinationals and cross country dependencies in the structure of foreign direct investment," Journal of International Economics, 60(2): 293-314.

Yotov, Y. V., R. Piermartini, J.-A. Monteiro, and M. Larch (2016). An Advanced Guide to Trade Policy Analysis: The Structural Gravity Model, Geneva: World Trade Organization. 


\section{Figures and tables}

Figure 1: PTA presence and depth between 2001 and 2012

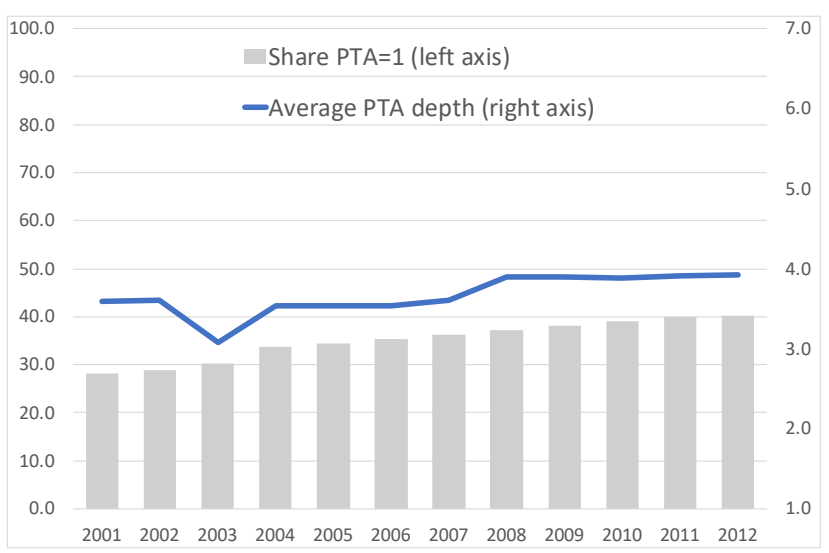

Source: Own elaboration using DESTA database. 
Table 1: Main characteristics for the presence and depth of PTAs between 2001 and 2012

\begin{tabular}{|c|c|c|c|c|c|c|c|c|c|}
\hline \multirow[b]{2}{*}{ With: } & \multicolumn{3}{|c|}{ All observations } & \multicolumn{3}{|c|}{ Country-pairs 1/ } & \multicolumn{3}{|c|}{$\begin{array}{c}\text { Country-pairs } \\
\text { with EU as partner }\end{array}$} \\
\hline & total & $\begin{array}{c}\text { share } \\
(\%)\end{array}$ & $\begin{array}{c}\text { share } \\
(\%) \text { if } \\
\text { PTA =1 }\end{array}$ & total & $\begin{array}{c}\text { share } \\
(\%)\end{array}$ & $\begin{array}{c}\text { share } \\
(\%) \text { if } \\
\text { PTA =1 }\end{array}$ & total & $\begin{array}{c}\text { share } \\
(\%)\end{array}$ & $\begin{array}{c}\text { share } \\
(\%) \text { if } \\
\text { PTA }=1\end{array}$ \\
\hline No PTA & 67,780 & 64.9 & & 5,183 & 61.0 & & 2,410 & 51.6 & \\
\hline PTA $($ dummy $=1)$ & 36,680 & 35.1 & & 3,320 & 39.0 & & 2,263 & 48.4 & \\
\hline PTA Depth $=1$ & 10,373 & 9.9 & 28.3 & 438 & 5.2 & 13.2 & 210 & 4.5 & 9.3 \\
\hline PTA Depth $=2$ & 6,030 & 5.8 & 16.4 & 556 & 6.5 & 16.7 & 139 & 3.0 & 6.1 \\
\hline PTA Depth $=3$ & 4,095 & 3.9 & 11.2 & 785 & 9.2 & 23.6 & 669 & 14.3 & 29.6 \\
\hline PTA Depth $=4$ & 2,035 & 1.9 & 5.5 & 210 & 2.5 & 6.3 & 145 & 3.1 & 6.4 \\
\hline PTA Depth $=5$ & 2,721 & 2.6 & 7.4 & 203 & 2.4 & 6.1 & 141 & 3.0 & 6.2 \\
\hline PTA Depth $=6$ & 1,176 & 1.1 & 3.2 & 163 & 1.9 & 4.9 & 35 & 0.7 & 1.5 \\
\hline PTA Depth $=7$ & 10,250 & 9.8 & 27.9 & 965 & 11.3 & 29.1 & 924 & 19.8 & 40.8 \\
\hline EU - single market & 6,570 & 6.3 & 17.9 & 693 & 8.2 & 20.9 & 693 & 14.8 & 20.9 \\
\hline Depth=7, excl. EU-sm & 3,680 & 3.5 & 10.0 & 272 & 3.2 & 8.2 & 231 & 4.9 & 20.0 \\
\hline Total & 104,460 & 100.0 & 100.0 & 8,503 & 100.0 & 100.0 & 4,673 & 100.0 & 100.0 \\
\hline
\end{tabular}

Notes: 1/ Excluding same country pairs. Sources: Own estimations using DESTA database. 
Table 2: Main FDI gravity regressions using yearly inward FDI stocks

\begin{tabular}{|c|c|c|c|c|c|c|}
\hline \multirow[b]{2}{*}{ variables: } & \multicolumn{4}{|c|}{ eq. 4: country-pair FE } & \multicolumn{2}{|c|}{ eq. 5: standard gravity } \\
\hline & (1) & $(2)$ & $(3)$ & (4) & $(5)$ & (6) \\
\hline PTA depth & $\begin{array}{c}0.051^{* * * *} \\
(0.017)\end{array}$ & $\begin{array}{c}0.043^{* *} \\
(0.017)\end{array}$ & & & $\begin{array}{c}0.191^{* * * *} \\
(0.032)\end{array}$ & \\
\hline PTA dummy & & & $\begin{array}{c}0.279 * * * \\
(0.062)\end{array}$ & $\begin{array}{c}0.272^{* * *} \\
(0.063)\end{array}$ & & $\begin{array}{c}0.411^{* *} \\
(0.166)\end{array}$ \\
\hline EU single market & & $\begin{array}{c}0.854^{* * *} \\
(0.105)\end{array}$ & & $\begin{array}{c}0.666^{* * *} \\
(0.083)\end{array}$ & $\begin{array}{c}1.029^{* * *} \\
(0.241)\end{array}$ & $\begin{array}{c}0.228 \\
(0.181)\end{array}$ \\
\hline $\log ($ Distance $)$ & & & & & $\begin{array}{c}-0.413^{* * *} \\
(0.102)\end{array}$ & $\begin{array}{c}-0.574^{* * *} \\
(0.112)\end{array}$ \\
\hline Common border & & & & & $\begin{array}{l}0.488^{*} \\
(0.258)\end{array}$ & $\begin{array}{c}0.611^{* * *} \\
(0.229)\end{array}$ \\
\hline Common language & & & & & $\begin{array}{c}1.224^{* * *} \\
(0.159)\end{array}$ & $\begin{array}{c}1.297^{* * *} \\
(0.146)\end{array}$ \\
\hline Colonial ties & & & & & $\begin{array}{c}3.016^{* * *} \\
(0.177)\end{array}$ & $\begin{array}{c}3.185^{* * *} \\
(0.173)\end{array}$ \\
\hline Observations & 75,228 & 75,228 & 75,228 & 75,228 & 77,512 & 77,512 \\
\hline
\end{tabular}

Notes: Dependent variable: FDI inward stocks. PPML estimations using country-pair clustering of standard errors, in parentheses: $* * * \mathrm{p}<0.01, * * \mathrm{p}<0.05, * \mathrm{p}<0.1$. Origincountry-time $\left(\mu_{i t}\right)$, destination-country-time $\left(\mu_{j t}\right)$, and country-par $\left(\mu_{i j}\right)$ fixed effects are not reported. PTA_dummy and PTA_depth are taken from the DESTA database. Source: Own estimations using UNCTAD bilateral FDI and CEPII databases. 
Table 3: Expected PTA impact on FDI by presence and value of PTA depth indicator

$\begin{array}{llc}\text { Policy } & \text { estimated } & \text { FDI effect } \\ \text { variable: } & \text { coefficient } & \text { (percentage) }\end{array}$

PTA presence (dummy) $\quad 0.272 \quad 31.3$

DESTA depth index

$\begin{array}{lcc}\text { depth }=1 & 0.043 & 4.4 \\ \text { depth }=2 & 0.086 & 9.0 \\ \text { depth }=3 & 0.129 & 13.8 \\ \text { depth }=4 & 0.172 & 18.8 \\ \text { depth }=5 & 0.215 & 24.0 \\ \text { depth }=6 & 0.258 & 29.4 \\ \text { depth }=7 & 0.301 & 35.1\end{array}$

EU single market $\quad 0.854 \quad 134.9$

Notes: Values taken from Table 2. Source: Own estimations using UNCTAD bilateral FDI, DESTA and CEPII databases. 
Table 4: Individually estimated coefficients for specific PTA depth levels and specific provisions

\begin{tabular}{lclc}
\hline & $\begin{array}{c}\text { estimated } \\
\text { coefficient }\end{array}$ & $\begin{array}{c}\text { significance } \\
\text { levels }\end{array}$ & $\begin{array}{c}\text { FDI effect } \\
\text { (percentage) }\end{array}$ \\
PTA depth level: & 0.112 & & \\
depth=1 & 0.102 & & \\
depth=2 & 0.213 & $* * *$ & 23.7 \\
depth=3 & -0.081 & & \\
depth=4 & 0.139 & $*$ & 14.9 \\
depth=5 & 0.107 & & \\
depth=6 & 0.239 & $* *$ & 27.0 \\
depth=7 & 0.060 & & \\
depth=7 \& non-EU $\backslash 1$ & & & \\
& & & 28.1 \\
PTA provisions: & 0.248 & $* * *$ & 25.1 \\
Full tariffs & 0.224 & $* * *$ & 21.2 \\
Standards & 0.192 & $* * *$ & 29.4 \\
Competition & 0.258 & $* * *$ & 23.0 \\
Services & 0.207 & $* *$ & 15.0 \\
Procurement & 0.140 & $*$ & 36.9 \\
Investments & 0.314 & $* * *$ & \\
IPRs & & & \\
& & &
\end{tabular}

Notes: All coefficients are estimated using Equation (4) with yearly FDI dat. $\backslash 1$ Here we only account for PTAs with depth level seven that do not include EU single market country-pairs. Source: Own estimations using the UNCTAD bilateral FDI and the DESTA databases. 
Table 5: FDI gravity regressions using yearly inward FDI stocks and BITs indicators

\begin{tabular}{|c|c|c|c|c|c|c|}
\hline variables & (1) & $(2)$ & (3) & (4) & $(5)$ & (6) \\
\hline BIT signed & $\begin{array}{c}0.265^{* * *} \\
(0.094)\end{array}$ & $\begin{array}{c}0.306^{* * *} \\
(0.090)\end{array}$ & $\begin{array}{c}0.304^{* * *} \\
(0.090)\end{array}$ & & & \\
\hline $\mathrm{BIT}$ in force & & & & $\begin{array}{c}0.336^{* * *} \\
(0.090)\end{array}$ & $\begin{array}{c}0.373^{* * *} \\
(0.0911)\end{array}$ & $\begin{array}{c}0.361^{* * *} \\
(0.0893)\end{array}$ \\
\hline PTA_depth & & $\begin{array}{c}0.043^{* *} \\
(0.017)\end{array}$ & & & $\begin{array}{c}0.043^{* *} \\
(0.0170)\end{array}$ & \\
\hline PTA_dummy & & & $\begin{array}{c}0.272^{* * *} \\
(0.063)\end{array}$ & & & $\begin{array}{c}0.271^{* * *} \\
(0.0627)\end{array}$ \\
\hline EU single market & & $\begin{array}{c}0.866^{* * *} \\
(0.105)\end{array}$ & $\begin{array}{c}0.678^{* * *} \\
(0.084)\end{array}$ & & $\begin{array}{c}0.869^{* * *} \\
(0.105)\end{array}$ & $\begin{array}{c}0.679^{* * *} \\
(0.0838)\end{array}$ \\
\hline Observations & 75,228 & 75,228 & 75,228 & 75,228 & 75,228 & 75,228 \\
\hline
\end{tabular}

Notes: Dependent variable: FDI inward stocks. PPML estimations using country-pair clustering of standard errors, in parentheses: $* * * \mathrm{p}<0.01,{ }^{* *} \mathrm{p}<0.05,{ }^{*} \mathrm{p}<0.1$. Origincountry-time $\left(\mu_{i t}\right)$, destination-country-time $\left(\mu_{j t}\right)$, and country-par $\left(\mu_{i j}\right)$ fixed effects are not reported. Source: Own estimations using UNCTAD bilateral FDI and BITs databases. 
Table 6: Estimated coefficients using yearly inward FDI stocks for alternative economic integration indicators

\begin{tabular}{|c|c|c|c|}
\hline & $\begin{array}{l}\text { estimated } \\
\text { coefficient }\end{array}$ & $\begin{array}{c}\text { significance } \\
\text { levels }\end{array}$ & $\begin{array}{c}\text { FDI effect } \\
\text { (percentage) }\end{array}$ \\
\hline \multicolumn{4}{|l|}{ WTO-based indicators: $1 \backslash$} \\
\hline Customs Union (CU) & 0.658 & $* * *$ & 93.1 \\
\hline Free trade agreement (FTA) & 0.128 & $* *$ & 13.7 \\
\hline Economic Integration Agreement (EIA) & 0.263 & $* * *$ & 30.1 \\
\hline Partial scope agreement (PS) & 0.208 & $*$ & 23.1 \\
\hline CU \& EIA & 0.681 & $* * *$ & 97.6 \\
\hline FTA \& EIA & 0.122 & $*$ & 13.0 \\
\hline $\mathrm{RTA} \backslash 1$ & 0.251 & $* * *$ & 28.5 \\
\hline \multicolumn{4}{|c|}{ Accounting separately for the EU single market: $\backslash 2$} \\
\hline Customs Union (CU) & -0.015 & & \\
\hline Free trade agreement (FTA) & 0.263 & $* * *$ & 30.1 \\
\hline Economic Integration Agreement (EIA) & 0.248 & $* * *$ & 28.1 \\
\hline Partial scope agreement (PS) & 0.207 & $*$ & 23.0 \\
\hline CU \& EIA & 0.632 & $* *$ & 88.1 \\
\hline FTA \& EIA & 0.247 & $* * *$ & 28.0 \\
\hline $\mathrm{RTA} \backslash 1$ & 0.250 & $* * *$ & 28.4 \\
\hline \multirow{2}{*}{\multicolumn{4}{|c|}{$\begin{array}{l}\text { Notes: } \backslash 1 \text { Taken from the updated version of the database from Egger and Larch (2008). } \\
\text { RTA }=1 \text { if any one of CU, FTA, EIA or PS is in place, and } 0 \text { otherwise. } 2 \backslash \text { These }\end{array}$}} \\
\hline & & & \\
\hline \multicolumn{4}{|c|}{$\begin{array}{c}\text { indicators treat the EU single market separately from these categories. In each of these } \\
\text { regressions the EU single market dummy is included (but not reported). Source: Own } \\
\text { estimations using UNCTAD bilateral FDI data. }\end{array}$} \\
\hline
\end{tabular}




\section{A Appendix}

\section{A.1 Deriving the FDI gravity model}

This annex derives the partial-equilibrium structural gravity model for FDI that we use in Section 3.1. Our objective is to aim for the simplest possible model, avoiding less essential complications. This is done in three stages. First, we analyse FDI by country pair in a friction-free world. In the second stage we introduce absolute FDI frictions. In the last stage we translate the results to a $n$-country world where also relative FDI friction costs matter.

The model is based on the knowledge-capital interpretation of FDI, where firms in country $i$ have proprietary knowledge $\left(M_{i t}\right)$ that can be used on a non-rival basis in several locations at time $t$. In this setting $M$ is regarded as FDI if the knowledge asset is applied in another country, under full or partial control of the owning firm. Assuming that all proprietary knowledge assets of all $k$ domestic firms can simply be aggregated to the national stock of knowledge capital, so that $M_{i t}=\sum_{k} M_{i t k}$. Larger and richer countries have more firms, and can invest more in the development of unique knowledge assets through firm-level and public institutions. We therefore assume that the national knowledge-capital stock is linearly proportional to current and past GDP:

$$
M_{i t}=\alpha_{i} Y_{i t}+M_{i t-1}
$$

in which $\alpha_{i}<1$ is the proportionality factor with respect to the country's current economic mass (measured as GDP), while $M_{i t-1}$ represents the cumulative knowledge stock from the past. If proprietary knowledge assets can somehow be protected and preserved, the use of the knowledge asset is non-rival. Firms are willing to 'lease' their proprietary knowledge asset to other countries in the form of FDI. To keep the model as simple as possible, we set the lagged component of national knowledge capital to zero, so that in a given year $t$ country $i$ will be prepared to supply FDI volume equal to $\alpha_{i} Y_{i t}$.

Consumers and firms have a preference for variety in their use of knowledgecapital assets, because they value foreign technologies, product designs and management methods. For any country $j$, this generates a positive demandpull for FDI. The size of this pull force is also proportional to the size of their economy $\beta_{j} Y_{j t}$, because larger countries tend to have more firms, more consumers, and a more complex set of intermediary industries. In a frictionfree world, the FDI push and pull forces generate a combined amount of 
bilateral FDI between each country pair:

$$
F D I_{i j t}^{\text {nofric }}=\alpha_{i} Y_{i t} \beta_{j} Y_{j t}
$$

The free flow of FDI is hampered as soon as we introduce absolute FDI frictions. Legal or statutory barriers to bilateral FDI represent a major source of absolute FDI frictions. On the side of the FDI-receiving country $j$ such access restrictions are represented by $\psi_{j i t}$. This may include red-tape barriers in the form of total FDI bans, negative lists that specify restrictions to the activity of multinationals in specific industries, protection of national champions, or any other access-related policy measures. Moreover, the FDI origin country $i$ could also use outflow restrictions $\psi_{i j t}$, e.g. when governments or firms define strategic or commercial knowledge assets that may not be transferred to country $j$ via FDI. ${ }^{45}$ Both factors diminish bilateral FDI:

$$
F D I_{i j t}^{a c c e s s}=\frac{F D I_{i j t}^{\text {nofric }}}{\left(1+\psi_{j i t}\right)\left(1+\psi_{i j t}\right)}
$$

If we further assume -without loss of generality- that all origin countries share the same $\alpha$, that all destination countries have the same $\beta$, and that $\phi_{i j t}$ indexes the combined absolute bilateral FDI frictions of the origin and destination country, then we have:

$$
F D I_{i j t}^{a c c e s s}=\frac{\alpha Y_{i t} \beta Y_{j t}}{\phi_{i j t}}
$$

$F D I_{i j t}^{\text {access }}$ represents the amount of FDI that country $i$ would invest in country $j$ in a world with only access-restricting (absolute) FDI frictions. However, the opportunity costs of investing in other countries plays no role in Equation 10. We now drop the latter condition. Relative FDI frictions can have many forms, but they all affect the opportunity costs of operating in a particular country versus operating in any other country. This may include various operational costs, such as distance (transport), infrastructure, communication (language differences), legal system (enforceability of contracts), government characteristics (efficiency, degree of business-mindedness, stability, corruption), labour quality and labour costs, corporate tax rate, and security conditions (affecting insurance and contingency costs). These are the elements that multinational firms typically evaluate before locating their operations in a particular country.

\footnotetext{
${ }^{45}$ Such bans may also be applied to proprietary knowledge assets when the destination country has the reputation that it does not respect or enforce intellectual property rights.
} 
The absolute FDI frictions dominate and precede the relative FDI friction, by setting the negative constraints that frame the possibilities for FDI location choice. After that, multinational firms choose their locations on the basis of relative FDI frictions and/or market size. Let $z_{i j t}$ be an index of the operating costs of FDI that firms from country $i$ would have when investing in destination country $j . z_{i j t}$ is then compared to other costs that multinationals have in all other countries, including their home country. Both these elements are consistently quantified by the so-called multilateral resistance (MR) terms. When viewed from the perspective of the FDI origin country $i$, the aggregator $P_{i t}$ gives the average of relative FDI friction costs in all possible destination countries (including the home country), weighted by the relative size of each economy:

$$
P_{i t}=\left[\sum_{j=1}^{N}\left(\frac{z_{i j t}}{\Pi_{j t}}\right)^{(1-\sigma)} \frac{Y_{j t}}{Y_{t}}\right]^{\frac{1}{1-\sigma}}
$$

The bilateral costs $z_{i j t}$ are normalised with $\Pi_{j t}$, an index for the average FDI friction cost, to be discussed below. The second factor is the size of country $j$ 's economy, as measured by its relative economic mass $\left(\frac{Y_{j t}}{Y_{t}}\right)$, where $Y_{t}=\sum Y_{j t}$ is world GDP. Finally, the inward multilateral resistance term $P_{i t}$ uses the constant elasticity of substitution $\sigma$ for a consistent aggregation and averaging of all national FDI friction costs, after weighing them by the relative economic size of each country. Recapitulating, $P_{i t}$ is the index that gives the average (relative) friction costs that each firm from country $i$ has when doing FDI, and after correcting for the size of each destination country. This index is important because it guides the FDI location choices of firms.

The combination of relative friction costs and market size decides whether a country is a preferred FDI location. This may vary by year. If $\frac{z_{i j t}}{\Pi_{j t}}<1$, the relative FDI friction costs are less than average and may not form an obstacle, but in the opposite case they form an obstacle for bilateral FDI. The second factor is the size of country $j$ 's economy, as measured by its relative economic mass $\left(\frac{Y_{j t}}{Y_{t}}\right)$. The combination of both elements decides whether a country is a preferred FDI location. A good score on one element may compensate a bad score on the other element. Countries that have the combination of a small economy $\left(Y_{j t} / \bar{Y}_{t}<1\right)$ and relatively high FDI friction costs may expect the least FDI, while most FDI will go to large countries with relatively low FDI friction costs.

The structural gravity model also accounts for differences in the policyrelated and geographical characteristics of each FDI origin. The latter may affect the costs of FDI and the willingness of national firms to engage in 
outward direct investment projects. Because the gravity model is all about the proportionality between economic mass and the intensity of cross-border FDI transactions, we must also account for such frictional (disturbance) factors. The full FDI gravity system therefore also holds the term $\Pi_{j t}$ for the outward MR terms, i.e. the relative outward FDI friction costs of FDI origin countries that potentially invest in country $j$, weighted by the relative size of the origin countries. Analogue to Equation 11, $\Pi_{j t}$ consistently aggregates the average outward MR for all (potential) origin countries, after accounting for differences in country size:

$$
\Pi_{j t}=\left[\sum_{i=1}^{N}\left(\frac{z_{j i t}}{P_{i t}}\right)^{(1-\sigma)} \frac{Y_{i t}}{Y_{t}}\right]^{\frac{1}{1-\sigma}}
$$

Mirroring Equation 11, country $i$ 's average inward MR terms $P_{i t}$ is used here to normalise the outward bilateral friction costs $z_{j i t}$.

Recall that Equation 10 yielded $F D I_{i j t}^{a c c e s s}$, the amount of FDI that country $i$ would invest in country $j$ in a world with only absolute (accessrestricting) FDI frictions. After elaborating the inward and outward MR terms we now move to the third stage of our analysis. Here we derive the full equation for bilateral FDI in a $n$-country world where relative FDI frictions also matter for FDI decisions. The friction-free FDI-push factor $\alpha Y_{i t}$ must be now corrected for the inward friction costs that firms from country $i$ encounter on average in its destination countries $\left(P_{i t}\right)$. These frictions lower the amount of outward FDI per unit of country $i$ 's GDP. Thus, the corrected FDI-push factor becomes: $\frac{\alpha Y_{i t}}{P_{i t}}$. Something similar holds for the FDI-pull factor coming from the destination countries $\left(\beta_{j} Y_{j t}\right)$. The average outward friction costs for their incoming FDI is given by $\Pi_{j t}$. This can be regarded as the expected average FDI acquisition costs that country $j$ 'incurs' to attract knowledge-capital FDI. The corrected FDI-demand pull then reduces to: $\frac{\beta Y_{j t}}{\Pi_{j t}}$. We may now derive the full equation for bilateral FDI:

$$
F D I_{i j t}^{\text {stock }}=\omega_{i j t} \frac{\alpha Y_{i t}}{P_{i t}} \frac{\beta Y_{j t}}{\Pi_{j t}}
$$

where $0 \leq \omega_{i j t} \leq 1$ is the FDI openness indicator, the inverse of the parameter $\phi_{i j t}$ for bilateral FDI access restrictions. With Equation 13 we have derived Equation 1 in the main text. 


\section{A.2 Additional tables}

Table A.1: Most frequent provisions by PTA depth level

\begin{tabular}{|c|c|c|c|c|c|c|}
\hline \multirow[b]{2}{*}{ With: } & \multicolumn{6}{|c|}{ Most frequent PTA provision combination } \\
\hline & First & share $(\%)$ & Second & share $(\%)$ & Third & share $(\%)$ \\
\hline PTA Depth $=1$ & Standards & 69.8 & Full tariffs & 23.3 & Services & 5.8 \\
\hline PTA Depth $=2$ & $\begin{array}{l}\text { Full tariffs + } \\
\text { standards }\end{array}$ & 94.9 & $\begin{array}{l}\text { Investment + } \\
\text { Services }\end{array}$ & 1.3 & $\begin{array}{l}\text { Full tariffs + } \\
\text { Services }\end{array}$ & 1.2 \\
\hline PTA Depth $=3$ & $\begin{array}{l}\text { Investment }+ \\
\text { Services }+ \\
\text { Competition }\end{array}$ & 29.3 & $\begin{array}{l}\text { Full tariffs }+ \\
\text { Standards + } \\
\text { IPRs }\end{array}$ & 15.4 & $\begin{array}{l}\text { Full tariffs }+ \\
\text { Standards }+ \\
\text { Procurement }\end{array}$ & 14.7 \\
\hline PTA Depth $=4$ & $\begin{array}{l}\text { Full tariffs }+ \\
\text { Standards }+ \\
\text { Services }+ \\
\text { Competition }\end{array}$ & 79.8 & $\begin{array}{l}\text { Full tariffs }+ \\
\text { Standards }+ \\
\text { Services }+ \\
\text { Procurement }\end{array}$ & 6.5 & $\begin{array}{l}\text { Full tariffs }+ \\
\text { Standards }+ \\
\text { Investment }+ \\
\text { Competition }\end{array}$ & 5.0 \\
\hline PTA Depth $=5$ & $\begin{array}{l}\text { All except: } \\
\text { Investment + } \\
\text { IPRs }\end{array}$ & 40.9 & $\begin{array}{l}\text { All except: } \\
\text { Procurement + } \\
\text { IPRs }\end{array}$ & 26.6 & $\begin{array}{l}\text { All except: } \\
\text { Investment + } \\
\text { Competition }\end{array}$ & 23.9 \\
\hline PTA Depth $=6$ & $\begin{array}{l}\text { All except: } \\
\text { IPRs }\end{array}$ & 43.6 & $\begin{array}{l}\text { All except: } \\
\text { Competition }\end{array}$ & 36.6 & $\begin{array}{l}\text { All except: } \\
\text { Procurement }\end{array}$ & 15.8 \\
\hline
\end{tabular}

Sources: Own estimations using DESTA database.

Table A.2: Correlations between main policy variables

\begin{tabular}{|c|c|c|c|c|c|c|c|c|c|c|c|c|c|}
\hline & & 1 & 2 & 3 & 4 & 5 & 6 & 7 & 8 & 9 & 10 & 11 & 12 \\
\hline 1 & FDI stocks & 1 & & & & & & & & & & & \\
\hline 2 & PTA_depth & 0.10 & 1 & & & & & & & & & & \\
\hline 3 & PTA_dummy & 0.06 & 0.80 & 1 & & & & & & & & & \\
\hline 4 & EU single market & -0.01 & 0.68 & 0.40 & 1 & & & & & & & & \\
\hline 5 & WB_pta_dummy & 0.07 & 0.77 & 0.72 & 0.46 & 1 & & & & & & & \\
\hline 6 & WB_tot_le & 0.14 & 0.86 & 0.62 & 0.64 & 0.81 & 1 & & & & & & \\
\hline 7 & WB_tot_pr & 0.12 & 0.84 & 0.66 & 0.54 & 0.88 & 0.94 & 1 & & & & & \\
\hline 8 & WB_core & 0.09 & 0.84 & 0.70 & 0.54 & 0.95 & 0.90 & 0.96 & 1 & & & & \\
\hline 9 & WB_pca & 0.10 & 0.86 & 0.66 & 0.65 & 0.88 & 0.95 & 0.99 & 0.96 & 1 & & & \\
\hline 10 & WTO FTA_dummy & 0.07 & 0.74 & 0.69 & 0.44 & 0.81 & 0.67 & 0.72 & 0.78 & 0.72 & 1 & & \\
\hline 11 & WTO RTA_dummy & 0.05 & 0.68 & 0.82 & 0.35 & 0.72 & 0.58 & 0.64 & 0.68 & 0.63 & 0.76 & 1 & \\
\hline 12 & BIT signed & 0.04 & 0.13 & 0.13 & 0.03 & 0.14 & 0.13 & 0.15 & 0.13 & 0.13 & 0.14 & 0.14 & 1 \\
\hline 13 & BITs in-force & 0.05 & 0.17 & 0.15 & 0.07 & 0.17 & 0.17 & 0.20 & 0.16 & 0.18 & 0.17 & 0.16 & 0.89 \\
\hline
\end{tabular}


Table A.3: FDI gravity regressions using 2-year average inward FDI stocks

\begin{tabular}{|c|c|c|c|c|c|c|}
\hline \multirow[b]{2}{*}{ variables: } & \multicolumn{4}{|c|}{ eq. 4: country-pair FE } & \multicolumn{2}{|c|}{ eq. 5: standard gravity } \\
\hline & (1) & $(2)$ & (3) & (4) & $(5)$ & $(6)$ \\
\hline PTA depth & $\begin{array}{c}0.060^{* * *} \\
(0.018)\end{array}$ & $\begin{array}{c}0.052^{* * *} \\
(0.018)\end{array}$ & & & $\begin{array}{c}0.195^{* * *} \\
(0.033)\end{array}$ & \\
\hline PTA dummy & & & $\begin{array}{c}0.277^{* * *} \\
(0.058)\end{array}$ & $\begin{array}{c}0.269 * * * \\
(0.059)\end{array}$ & & $\begin{array}{c}0.417^{* *} \\
(0.163)\end{array}$ \\
\hline EU single market & & $\begin{array}{c}0.873^{* * *} \\
(0.107)\end{array}$ & & $\begin{array}{c}0.650 * * * \\
(0.083)\end{array}$ & $\begin{array}{c}1.078^{* * *} \\
(0.233)\end{array}$ & $\begin{array}{c}0.249 \\
(0.168)\end{array}$ \\
\hline $\log ($ Distance $)$ & & & & & $\begin{array}{c}-0.400^{* * *} \\
(0.0991)\end{array}$ & $\begin{array}{c}-0.572^{* * *} \\
(0.109)\end{array}$ \\
\hline Common border & & & & & $\begin{array}{l}0.503^{*} \\
(0.258)\end{array}$ & $\begin{array}{c}0.615^{* * *} \\
(0.229)\end{array}$ \\
\hline Common language & & & & & $\begin{array}{c}1.234^{* * *} \\
(0.160)\end{array}$ & $\begin{array}{c}1.299^{* * *} \\
(0.146)\end{array}$ \\
\hline Colonial ties & & & & & $\begin{array}{c}2.953^{* * *} \\
(0.187)\end{array}$ & $\begin{array}{c}3.167^{* * *} \\
(0.175)\end{array}$ \\
\hline Observations & 38,319 & 38,319 & 38,319 & 38,319 & 39,647 & 39,647 \\
\hline
\end{tabular}

Notes: Dependent variable: FDI inward stocks, using 2-year averages. PPML estimations using country-pair clustering of standard errors, in parentheses: ${ }^{* * *} \mathrm{p}<0.01,{ }^{* *} \mathrm{p}<0.05$, $* \mathrm{p}<0.1$. Origin-country-time $\left(\mu_{i t}\right)$, destination-country-time $\left(\mu_{j t}\right)$, and country-par $\left(\mu_{i j}\right)$ fixed effects are not reported. PTA_dummy and PTA_depth are taken from the DESTA database. Source: Own estimations using UNCTAD bilateral FDI and CEPII databases. 
Table A.4: FDI gravity regressions using 3-year average FDI inward stock data

\begin{tabular}{|c|c|c|c|c|c|c|}
\hline \multirow[b]{2}{*}{ variables: } & \multicolumn{4}{|c|}{ eq. 4: country-pair FE } & \multicolumn{2}{|c|}{ eq. 5: standard gravity } \\
\hline & (1) & $(2)$ & $(3)$ & $(4)$ & $(5)$ & $(6)$ \\
\hline PTA depth & $\begin{array}{c}0.060^{* * *} \\
(0.020)\end{array}$ & $\begin{array}{c}0.053^{* * *} \\
(0.019)\end{array}$ & & & $\begin{array}{c}0.207^{* * *} \\
(0.033)\end{array}$ & \\
\hline PTA dummy & & & $\begin{array}{c}0.253^{* * *} \\
(0.065)\end{array}$ & $\begin{array}{c}0.251^{* * *} \\
(0.065)\end{array}$ & & $\begin{array}{c}0.444^{* * *} \\
(0.168)\end{array}$ \\
\hline EU single market & & $\begin{array}{c}0.884^{* * *} \\
(0.110)\end{array}$ & & $\begin{array}{c}0.659 * * * \\
(0.085)\end{array}$ & $\begin{array}{c}1.095^{* * *} \\
(0.230)\end{array}$ & $\begin{array}{c}0.223 \\
(0.169)\end{array}$ \\
\hline $\log ($ Distance $)$ & & & & & $\begin{array}{c}-0.388^{* * *} \\
(0.0997)\end{array}$ & $\begin{array}{c}-0.575^{* * *} \\
(0.110)\end{array}$ \\
\hline Common border & & & & & $\begin{array}{l}0.489^{*} \\
(0.255)\end{array}$ & $\begin{array}{c}0.604^{* * *} \\
(0.224)\end{array}$ \\
\hline Common language & & & & & $\begin{array}{c}1.230^{* * *} \\
(0.160)\end{array}$ & $\begin{array}{c}1.298^{* * *} \\
(0.145)\end{array}$ \\
\hline Colonial ties & & & & & $\begin{array}{c}2.920^{* * *} \\
(0.190)\end{array}$ & $\begin{array}{c}3.150^{* * *} \\
(0.175)\end{array}$ \\
\hline Observations & 26,317 & 26,317 & 26,317 & 26,317 & 27,285 & 27,285 \\
\hline
\end{tabular}

Notes: Dependent variable: FDI inward stocks, using 3-year averages. PPML estimations using country-pair clustering of standard errors, in parentheses: ${ }^{* * *} \mathrm{p}<0.01,{ }^{* *} \mathrm{p}<0.05$, $* \mathrm{p}<0.1$. Origin-country-time $\left(\mu_{i t}\right)$, destination-country-time $\left(\mu_{j t}\right)$, and country-par $\left(\mu_{i j}\right)$ fixed effects are not reported. PTA_dummy and PTA_depth are taken from the DESTA database. Source: Own estimations using UNCTAD bilateral FDI and CEPII databases. 
Table A.5: FDI gravity regressions using 4-year average inward FDI stocks

\begin{tabular}{|c|c|c|c|c|c|c|}
\hline \multirow[b]{2}{*}{ variables: } & \multicolumn{4}{|c|}{ eq. 4: country-pair FE } & \multicolumn{2}{|c|}{ eq. 5: standard gravity } \\
\hline & (1) & $(2)$ & (3) & (4) & $(5)$ & (6) \\
\hline PTA depth & $\begin{array}{c}0.073^{* * *} \\
(0.022)\end{array}$ & $\begin{array}{c}0.066^{* * *} \\
(0.022)\end{array}$ & & & $\begin{array}{c}0.205^{* * *} \\
(0.033)\end{array}$ & \\
\hline PTA dummy & & & $\begin{array}{c}0.274^{* * *} \\
(0.061)\end{array}$ & $\begin{array}{c}0.265^{* * *} \\
(0.062)\end{array}$ & & $\begin{array}{c}0.472^{* * *} \\
(0.164)\end{array}$ \\
\hline EU single market & & $\begin{array}{c}0.892^{* * *} \\
(0.117)\end{array}$ & & $\begin{array}{c}0.615^{* * *} \\
(0.084)\end{array}$ & $\begin{array}{c}1.108^{* * *} \\
(0.231)\end{array}$ & $\begin{array}{c}0.230 \\
(0.168)\end{array}$ \\
\hline $\log ($ Distance $)$ & & & & & $\begin{array}{c}-0.383^{* * *} \\
(0.099)\end{array}$ & $\begin{array}{c}-0.567^{* * *} \\
(0.109)\end{array}$ \\
\hline Common border & & & & & $\begin{array}{c}0.516^{* *} \\
(0.259)\end{array}$ & $\begin{array}{c}0.607^{* * *} \\
(0.229)\end{array}$ \\
\hline Common language & & & & & $\begin{array}{c}1.222^{* * *} \\
(0.161)\end{array}$ & $\begin{array}{c}1.288^{* * *} \\
(0.147)\end{array}$ \\
\hline Colonial ties & & & & & $\begin{array}{c}2.930^{* * *} \\
(0.191)\end{array}$ & $\begin{array}{c}3.163^{* * *} \\
(0.174)\end{array}$ \\
\hline Observations & 19,519 & 19,519 & 19,519 & 19,519 & 20,340 & 20,340 \\
\hline
\end{tabular}

Notes: Dependent variable: FDI inward stocks, using 4-year averages. PPML estimations using country-pair clustering of standard errors, in parentheses: ${ }^{* * *} \mathrm{p}<0.01,{ }^{* *} \mathrm{p}<0.05$, $* \mathrm{p}<0.1$. Origin-country-time $\left(\mu_{i t}\right)$, destination-country-time $\left(\mu_{j t}\right)$, and country-par $\left(\mu_{i j}\right)$ fixed effects are not reported. PTA_dummy and PTA_depth are taken from the DESTA database. Source: Own estimations using UNCTAD bilateral FDI and CEPII databases. 
Table A.6: FDI gravity regressions using yearly inward FDI stocks and the PTA indicators from the World Bank database

\begin{tabular}{|c|c|c|c|c|c|c|c|c|c|c|}
\hline variables: & (1) & (2) & (3) & (4) & (5) & (6) & (7) & (8) & (9) & (10) \\
\hline wb_pta_dummy & $\begin{array}{c}0.346^{* * *} \\
(0.058)\end{array}$ & $\begin{array}{c}0.316^{* * *} \\
(0.062)\end{array}$ & & & & & & & & \\
\hline wb_tot_le & & & $\begin{array}{c}0.024^{* * *} \\
(0.005)\end{array}$ & $\begin{array}{c}0.041^{* * *} * \\
(0.010)\end{array}$ & & & & & & \\
\hline wb_tot_pr & & & & & $\begin{array}{c}0.022^{* * *} \\
(0.004)\end{array}$ & $\begin{array}{c}0.026^{* * *} \\
(0.006)\end{array}$ & & & & \\
\hline wb_core & & & & & & & $\begin{array}{c}0.026^{* * * *} \\
(0.006)\end{array}$ & $\begin{array}{c}0.023^{* * *} \\
(0.007)\end{array}$ & & \\
\hline wb_pca & & & & & & & & & $\begin{array}{c}0.145^{* * *} \\
(0.028)\end{array}$ & $\begin{array}{c}0.168^{* * *} \\
(0.045)\end{array}$ \\
\hline EU single market & & $\begin{array}{c}0.418^{* * *} \\
(0.097)\end{array}$ & & $\begin{array}{c}-0.646^{*} \\
(0.359)\end{array}$ & & $\begin{array}{l}-0.150 \\
(0.196)\end{array}$ & & $\begin{array}{c}0.349^{* * *} \\
(0.132)\end{array}$ & & $\begin{array}{l}-0.154 \\
(0.243)\end{array}$ \\
\hline Observations & 75,228 & 75,228 & 75,228 & 75,228 & 75,228 & 75,228 & 75,228 & 75,228 & 75,228 & 75,228 \\
\hline
\end{tabular}

Notes: Dependent variable: yearly FDI inward stocks. PPML estimations using countrypair clustering of standard errors, in parentheses: $* * * \mathrm{p}<0.01,{ }^{*} * \mathrm{p}<0.05,{ }^{*} \mathrm{p}<0.1$. Origin-country-time $\left(\mu_{i t}\right)$, destination-country-time $\left(\mu_{j t}\right)$, and country-par $\left(\mu_{i j}\right)$ fixed effects are not reported. The PTA_wb dummy and the PTA depth indicators ( $w b \_t o t \_l e$, $w b \_t o t \_p r, w b \_c o r e$, and $\left.w b \_p c a\right)$ are explained in Section 4.3.1. Source: Own estimations using UNCTAD bilateral FDI and World Bank databases. 
Table A.7: FDI gravity regressions using yearly inward FDI stocks, with and without domestic investment stocks

\begin{tabular}{|c|c|c|c|c|}
\hline \multirow[b]{2}{*}{ variables } & \multicolumn{2}{|c|}{ Main specification } & \multicolumn{2}{|c|}{$\begin{array}{l}\text { Excluding domestic } \\
\text { investment stocks }\end{array}$} \\
\hline & (1) & (2) & (3) & (4) \\
\hline PTA depth & $\begin{array}{c}0.043^{* *} \\
(0.017)\end{array}$ & & $\begin{array}{l}-0.002 \\
(0.010)\end{array}$ & \\
\hline PTA dummy & & $\begin{array}{c}0.272^{* * *} \\
(0.063)\end{array}$ & & $\begin{array}{l}-0.076 \\
(0.049)\end{array}$ \\
\hline EU single market & $\begin{array}{c}0.866^{* * *} \\
(0.105)\end{array}$ & $\begin{array}{c}0.678^{* * *} \\
(0.084)\end{array}$ & $\begin{array}{l}0.170^{*} \\
(0.102)\end{array}$ & $\begin{array}{l}0.184^{*} \\
(0.098)\end{array}$ \\
\hline BIT signed & $\begin{array}{c}0.306^{* * *} \\
(0.090)\end{array}$ & $\begin{array}{c}0.304^{* * *} \\
(0.090)\end{array}$ & $\begin{array}{l}0.0241 \\
(0.052)\end{array}$ & $\begin{array}{c}0.020 \\
(0.051)\end{array}$ \\
\hline Observations & 75,228 & 75,228 & 72,739 & 72,739 \\
\hline
\end{tabular}

Notes: Dependent variable: FDI inward stocks. PPML estimations using country-pair clustering of standard errors, in parentheses: ${ }^{* * *} \mathrm{p}<0.01,{ }^{* *} \mathrm{p}<0.05,{ }^{*} \mathrm{p}<0.1$. Origincountry-time $\left(\mu_{i t}\right)$, destination-country-time $\left(\mu_{j t}\right)$, and country-par $\left(\mu_{i j}\right)$ fixed effects are not reported. Source: Own estimations using UNCTAD bilateral FDI and DESTA databases. 
Table A.8: FDI gravity regressions using yearly inward FDI stocks and excluding countries that are a classified as tax havens

\begin{tabular}{|c|c|c|c|c|}
\hline \multirow[b]{2}{*}{ variables } & \multicolumn{2}{|c|}{ Main specification } & \multicolumn{2}{|c|}{$\begin{array}{c}\text { Excluding domestic } \\
\text { investment stocks }\end{array}$} \\
\hline & (1) & $(2)$ & $(3)$ & (4) \\
\hline \multirow[t]{2}{*}{ PTA depth } & $0.043^{* *}$ & & 0.028 & \\
\hline & $(0.017)$ & & $(0.018)$ & \\
\hline \multirow[t]{2}{*}{ PTA dummy } & & $0.272^{* * *}$ & & $0.140^{*}$ \\
\hline & & $(0.063)$ & & $(0.080)$ \\
\hline \multirow[t]{2}{*}{ EU single market } & $0.866^{* * *}$ & $0.678^{* * *}$ & $0.761^{* * *}$ & $0.643^{* * *}$ \\
\hline & $(0.105)$ & $(0.084)$ & $(0.108)$ & $(0.084)$ \\
\hline \multirow[t]{2}{*}{ BIT signed } & $0.306^{* * *}$ & $0.304^{* * *}$ & $0.279 * * *$ & $0.277^{* * *}$ \\
\hline & $(0.090)$ & $(0.090)$ & $(0.097)$ & $(0.096)$ \\
\hline Observations & 75,228 & 75,228 & 59,506 & 59,506 \\
\hline
\end{tabular}

Notes: Dependent variable: yearly inward FDI stocks. PML estimations using countrypair clustering of standard errors, in parentheses: $* * * \mathrm{p}<0.01,{ }^{* *} \mathrm{p}<0.05,{ }^{*} \mathrm{p}<0.1$. Origincountry-time $\left(\mu_{i t}\right)$, destination-country-time $\left(\mu_{j t}\right)$, and country-par $\left(\mu_{i j}\right)$ fixed effects are not reported. Source: Own estimations using UNCTAD bilateral FDI and DESTA databases.

Table A.9: FDI gravity regressions using FDI inflows for yearly data and different year averages

\begin{tabular}{|c|c|c|c|c|c|c|}
\hline \multirow[b]{2}{*}{ variables } & \multicolumn{2}{|c|}{ Yearly FDI stocks } & \multicolumn{2}{|c|}{$\begin{array}{l}\text { 3-year average } \\
\text { FDI stocks }\end{array}$} & \multicolumn{2}{|c|}{$\begin{array}{l}\text { 4-year average } \\
\text { FDI stocks }\end{array}$} \\
\hline & (1) & (2) & (3) & (4) & (5) & (6) \\
\hline PTA depth & $\begin{array}{c}0.012 \\
(0.030)\end{array}$ & & $\begin{array}{l}-0.014 \\
(0.013)\end{array}$ & & $\begin{array}{c}0.045^{* * *} \\
(0.011)\end{array}$ & \\
\hline PTA dummy & & $\begin{array}{c}0.085 \\
(0.134)\end{array}$ & & $\begin{array}{c}-0.01 \\
(0.085)\end{array}$ & & $\begin{array}{c}0.094^{* *} \\
(0.044)\end{array}$ \\
\hline EU single market & $\begin{array}{c}0.678^{* * * *} \\
(0.178)\end{array}$ & $\begin{array}{c}0.712^{* * * *} \\
(0.185)\end{array}$ & $\begin{array}{c}0.427^{* *} \\
(0.184)\end{array}$ & $\begin{array}{c}0.484^{* * *} \\
(0.182)\end{array}$ & $\begin{array}{l}0.136^{*} \\
(0.073)\end{array}$ & $\begin{array}{c}0.059 \\
(0.075)\end{array}$ \\
\hline BIT in force & $\begin{array}{c}0.652^{* * *} \\
(0.230)\end{array}$ & $\begin{array}{c}0.652^{* * *} \\
(0.230)\end{array}$ & $\begin{array}{c}0.248 \\
(0.159)\end{array}$ & $\begin{array}{c}0.247 \\
(0.159)\end{array}$ & $\begin{array}{c}0.199^{* * *} \\
(0.066)\end{array}$ & $\begin{array}{c}0.193^{* * *} \\
(0.066)\end{array}$ \\
\hline Observations & 72,991 & 72,991 & 19,951 & 19,951 & 12,501 & 12,501 \\
\hline
\end{tabular}

Notes: Dependent variable: FDI inflows. PML estimations using country-pair clustering of standard errors, in parentheses: ${ }^{* * *} \mathrm{p}<0.01,{ }^{* *} \mathrm{p}<0.05,{ }^{*} \mathrm{p}<0.1$. Origin-country-time $\left(\mu_{i t}\right)$, destination-country-time $\left(\mu_{j t}\right)$, and country-par $\left(\mu_{i j}\right)$ fixed effects are not reported. Source: Own estimations using UNCTAD bilateral FDI, WDI and DESTA databases. 
Table A.10: FDI gravity regressions using yearly inward FDI stocks with lags and leads

\begin{tabular}{lclc}
\hline & $\begin{array}{c}\text { estimated } \\
\text { coefficient }\end{array}$ & $\begin{array}{c}\text { significance } \\
\text { levels }\end{array}$ & $\begin{array}{c}\text { FDI effect } \\
\text { (percentage) }\end{array}$ \\
PTA dummy: & & $* *$ & \\
Lagged 1 year & 0.250 & $* * *$ & 28.4 \\
Lagged 2 years & 0.199 & $* * *$ & 22.0 \\
Lagged 3 years & 0.146 & $* * *$ & 15.7 \\
Forward 1 year & 0.280 & $* * *$ & 32.3 \\
Forward 2 years & 0.261 & $* * *$ & 29.8 \\
Forward 3 years & 0.284 & $* * *$ & 32.8 \\
& & & \\
PTA depth: & & $* *$ & 4.0 \\
Lagged 1 year & 0.039 & $* *$ & 3.5 \\
Lagged 2 years & 0.035 & $* *$ & 3.3 \\
Lagged 3 years & 0.033 & $* *$ & 3.9 \\
Forward 1 year & 0.038 & $* * *$ & 4.1 \\
Forward 2 years & 0.040 & $* * *$ & 3.2 \\
Forward 3 years & 0.032 & $* * *$ & \\
& & & \\
\hline
\end{tabular}

Notes: Dependent variable: yearly FDI inward stocks. PPML estimations using countrypair clustering of standard errors, in parentheses: ${ }^{* * *} \mathrm{p}<0.01,{ }^{* *} \mathrm{p}<0.05,{ }^{*} \mathrm{p}<0.1$. Origincountry-time $\left(\mu_{i t}\right)$, destination-country-time $\left(\mu_{j t}\right)$, and country-par $\left(\mu_{i j}\right)$ fixed effects are not reported. EU single market dummy included in all regressions.

Source: Own estimations using UNCTAD bilateral FDI and DESTA databases. 

KVL Economic Policy Research

\section{KVL Discussion Papers}

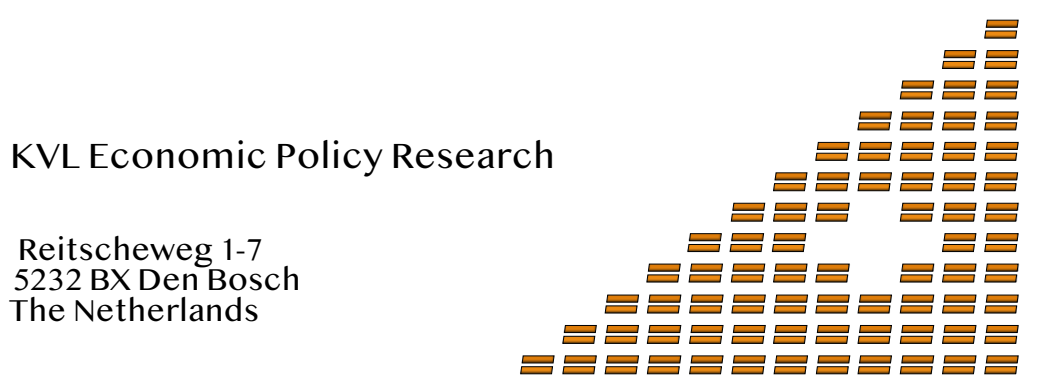

